Atmos. Chem. Phys., 13, 4033-4055, 2013

www.atmos-chem-phys.net/13/4033/2013/

doi:10.5194/acp-13-4033-2013

(C) Author(s) 2013. CC Attribution 3.0 License.

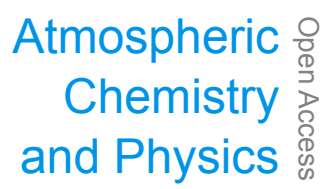

(c) (P)

\title{
Black carbon concentration and deposition estimations in Finland by the regional aerosol-climate model REMO-HAM
}

\author{
A. I. Hienola ${ }^{1}$, J.-P. Pietikäinen ${ }^{1}$, D. Jacob ${ }^{2,3}$, R. Pozdun ${ }^{2,3, \dagger}$, T. Petäjä ${ }^{4}$, A.-P. Hyvärinen ${ }^{1}$, L. Sogacheva ${ }^{1}$, \\ V.-M. Kerminen ${ }^{4}$, M. Kulmala ${ }^{4}$, and A. Laaksonen ${ }^{1}$ \\ ${ }^{1}$ Finnish Meteorological Institute, Erik Palmenin aukio 1, 00101 Helsinki, Finland \\ ${ }^{2}$ Max Planck Institute for Meteorology, Bundersstrasse 53, 20146 Hamburg, Germany \\ ${ }^{3}$ Climate Service Center, Chilehaus - Eingang B, Fischertwiette 1, 20095 Hamburg, Germany \\ ${ }^{4}$ Department of Physics, Division of Atmospheric Sciences and Geophysics, University of Helsinki, P.O. Box 64, 00014 \\ Helsinki, Finland \\ ${ }^{\dagger}$ Deceased September 2011. RIP
}

Correspondence to: A. I. Hienola (anca.hienola@fmi.fi)

Received: 23 July 2012 - Published in Atmos. Chem. Phys. Discuss.: 18 September 2012

Revised: 22 March 2013 - Accepted: 27 March 2013 - Published: 18 April 2013

\begin{abstract}
The prediction skill of the regional aerosolclimate model REMO-HAM was assessed against the black carbon (BC) concentration measurements from five locations in Finland, with focus on Hyytiälä station for the year 2005. We examined to what extent the model is able to reproduce the measurements using several statistical tools: median comparison, overlap coefficient (OVL; the common area under two probability distributions curves) and $\mathrm{Z}$ score (a measure of standard deviation, shape and spread of the distributions). The results of the statistics showed that the model is biased low. The local and regional emissions of $\mathrm{BC}$ have a significant contribution, and the model tendency to flatten the observed BC is most likely dominated by the lack of domestic burning of biofuel in the emission inventories. A further examination of the precipitation data from both measurements and model showed that there is no correlation between REMO's excessive precipitation and BC underestimation. This suggests that the excessive wet removal is not the main cause of the low black carbon concentration output. In addition, a comparison of wind directions in relation with high black carbon concentrations shows that REMO-HAM is able to predict the $\mathrm{BC}$ source directions relatively well. $\mathrm{Cu}$ mulative black carbon deposition fluxes over Finland were estimated, including the deposition on snow.
\end{abstract}

\section{Introduction}

Black carbon (BC), operationally defined as the lightabsorbing fraction of carbonaceous aerosols, is an air pollutant formed through the incomplete combustion of fossil fuels, biofuel, and biomass. Both natural processes and anthropogenic activities are responsible for the emission of BC (Cooke et al., 1999). Black carbon particles absorb solar radiation, causing an increase in their temperature and emission of thermal-infrared radiation into the surrounding space. When BC deposits onto a frozen surface, such as snow or ice, the immediate effects are changing the reflectivity of the snow and heating the surface, both of them promoting ice and snow melting (Jacobson, 2004; Hansen and Nazarenko, 2004). Deposition of BC on snow is thought to affect the climate on regional and global scales. Jacobson (2004) predicted a reduction in snow albedo due to BC deposition of $1 \%$ in the Northern Hemisphere and $0.4 \%$ globally, resulting in an increase in global temperature of $0.06^{\circ} \mathrm{C}$. Hansen et al. (2005), based on a simulated deposition of BC, parameterized the changes in snow albedo, calculated a positive radiative forcing of $0.15 \mathrm{~W} \mathrm{~m}^{-2}$ and estimated a global warming of $0.24^{\circ} \mathrm{C}$.

Due to the numerous and complex mechanisms through which $\mathrm{BC}$ affects the radiation balance, estimating the impact of black carbon on climate change remains largely uncertain. As black carbon has a relatively short lifetime in the 
atmosphere (a couple of days to less than 2 weeks), it has been considered as a candidate species for immediate reduction of climate forcing, as part of short-term climate control strategies (Levy et al., 2008; Bond et al., 2011; UNEP and WMO, 2011). Therefore, proper BC modelling is needed and stands out as being of great interest among atmospheric scientists. However, model simulation of $\mathrm{BC}$ is hindered by various factors. For instance, accurate knowledge of $\mathrm{BC}$ emissions is essential for a proper model prediction of black carbon. Global BC emission inventories show large discrepancies due to differences in emission factors and sources. According to Bond et al. (2004), emission inventories can have an uncertainty of a factor of 2 , while Ramanathan and Carmichael (2008) give a factor of two to five on regional scale, and a minimum of $\pm 50 \%$ on global scale. These uncertainties play an even more significant role in regional simulations, as at smaller scale the actual emissions are more likely to deviate even more from the annual or monthly mean inventory.

In addition to the uncertainties due to the inaccuracy of the input data, current models - whether global or regional are still agonizing due to the great difficulties in representing the complexities of aerosol dynamics (and in this particular case the evolution of BC) in a rigorous way. Vignati et al. (2010b) underlined the importance of an adequate characterization of the black carbon aging process in the models. After being emitted to the atmosphere, $\mathrm{BC}$ goes through a series of chemical and physical transformations. Condensation of soluble material onto $\mathrm{BC}$, coagulation of $\mathrm{BC}$ particles with soluble particles and photochemistry are contributing processes collectively known as aging. The aging process should not be overlooked, as it changes the particles' composition and hence their physico-chemical properties (Furutani et al., 2008; Decesari et al., 2006). For instance, the particle's hygroscopicity is modified from a hydrophobic state towards a more hydrophilic state. The hygroscopicity of BC particles defines which removal process - wet or dry deposition - will be more effective, hence impacting the black carbon lifetime by an estimated one order of magnitude (Croft et al., 2005). Observations have shown that wet deposition represents 70$85 \%$ of the tropospheric sink for the carbonaceous aerosols (Pöschl, 2005). However, wet deposition is considered one of the most uncertain processes in models (Textor et al., 2006).

To date, many global models have been used to study the spatial and temporal evolution of BC particles, as well as their physical properties. In early attempts to model black carbon concentrations, modellers assumed that $\mathrm{BC}$ was externally mixed and had a constant size distribution (Haywood and Shine, 1995; Tegen et al., 1997). More up-to-date models include BC size fractionation and internal mixing (Stier et al., 2005; Vignati et al., 2010a; Schwarz et al., 2010; Gilardoni et al., 2011). For a very comprehensive overview of the BC simulation, the reader is directed to Koch et al. (2009), who compared 17 models from the AEROCOM aerosol model comparison with several types of observation, revealing large
$\mathrm{BC}$ discrepancies, coming mostly from $\mathrm{BC}$ inventories and from the models' characteristics.

At regional level, several chemistry transport models have been applied to calculate BC concentrations. For instance Schaap et al. (2004) presented the LOTOS model simulations for the year 1995 over Europe. The comparison with the experimental data showed that the model underestimates the $\mathrm{PM}_{2.5}$ levels, mostly because of the underprediction of the carbonaceous material. The authors concluded that the most important cause of the discrepancy may be the emission inventories for BC. Tsyro et al. (2007) and Simpson et al. (2007) applied the EMEP chemical transport model to calculate elemental carbon (EC) and, respectively, EC and OC concentrations over Europe for the years 2002-2004. The model underestimates the EC measurements by $19 \%$ on average, overestimating in the Nordic countries and underestimating in Southern Europe.

Although numerous regional aerosol-climate models exist, few have been used to analyse black carbon distribution and properties. Carmichael et al. (2003) used the regional scale transport model CFORS to calculate BC concentrations (among other species) and presented a comparison with aircraft measurements above Asia. Using the same model, Uno et al. (2003) went into a more detailed analysis of black carbon, using surface $\mathrm{BC}$ measurements at five remote Japanese islands for model validation. In both cases, the CFORS model seemed to underestimate black carbon levels. Wu et al. (2004) investigated the emission, transport and distribution of black-carbon-containing aerosols and their radiative effect over China by means of the regional climate model RIEMS. Solmon et al. (2006) implemented a simplified anthropogenic aerosol model within the regional climate model RegCM and ran it over a large domain extending from Northern Europe to southern tropical Africa. The model evaluation was carried out in terms of black carbon, organic carbon and sulphate surface concentrations, and aerosol optical depths. More recently, Wu et al. (2008), using regional climate model RegCM3, simulated the direct radiative effects of $\mathrm{BC}$ over the Asian region and investigated the possible climate change induced by BC. However, the authors, among other simplifications, considered in their model only black carbon as such, i.e. without any internal or external mixing with other kind of aerosols, which can lead to errors in the overall overestimation of the BC warming (Cappa et al., 2012).

To the authors' knowledge, no other regional aerosolclimate model studies regarding black carbon have been conducted in the recent years. The lack of interest in the subject is surprising, given the fact that regional models - with their relatively higher resolutions - could bring an enhanced understanding of the behaviour of $\mathrm{BC}$ aerosols and their climatic impact on regional scale.

In this study we apply and explore the performance of our current version of regional aerosol-climate model REMOHAM in terms of black carbon near-surface concentrations and deposition fluxes in Finland. The authors stress the fact 
Table 1. The modal structure of HAM-M7. $\mathrm{N}_{i}$ denotes the aerosol number of mode $i$ and $\mathrm{M}_{i}^{j}$ denotes the mass of compound $j$. The dry radius $r$ shows the limits of different modes (Stier et al. (2005)).

\begin{tabular}{lll}
\hline Mode & Soluble / Mixed & Insoluble \\
\hline $\begin{array}{l}\text { Nucleation mode } \\
r \leq 5 \mathrm{~nm}\end{array}$ & $\mathrm{~N}_{1}, \mathrm{M}_{1}^{\mathrm{S}}$ & \\
$\begin{array}{l}\text { Aitken mode } \\
5 \mathrm{~nm}<r \leq 50 \mathrm{~nm}\end{array}$ & $\mathrm{~N}_{2}, \mathrm{M}_{2}^{\mathrm{S}}, \mathrm{M}_{2}^{\mathrm{BC}}, \mathrm{M}_{2}^{\mathrm{POM}}$ & $\mathrm{N}_{5}, \mathrm{M}_{5}^{\mathrm{BC}}, \mathrm{M}_{5}^{\mathrm{POM}}$ \\
$\begin{array}{l}\text { Accumulation mode } \\
50 \mathrm{~nm}<r \leq 0.5 \mu \mathrm{m}\end{array}$ & $\mathrm{N}_{3}, \mathrm{M}_{3}^{\mathrm{S}}, \mathrm{M}_{3}^{\mathrm{BC}}, \mathrm{M}_{3}^{\mathrm{POM}}, \mathrm{M}_{3}^{\mathrm{SS}}, \mathrm{M}_{3}^{\mathrm{DU}}$ & $\mathrm{N}_{6}, \mathrm{M}_{6}^{\mathrm{DU}}$ \\
$\begin{array}{l}\text { Coarse mode } \\
r>0.5 \mu \mathrm{m}\end{array}$ & $\mathrm{N}_{4}, \mathrm{M}_{4}^{\mathrm{S}}, \mathrm{M}_{4}^{\mathrm{BC}}, \mathrm{M}_{4}^{\mathrm{POM}}, \mathrm{M}_{4}^{\mathrm{SS}}, \mathrm{M}_{4}^{\mathrm{DU}}$ & $\mathrm{N}_{7}, \mathrm{M}_{7}^{\mathrm{DU}}$ \\
\hline
\end{tabular}

that this work is only the first step towards a more comprehensive development effort of the present regional climate model.

The outline of the article is as follows: a brief description of the model, the sites and the instrumentation is given in Section 2. Section 3 deals with the comparison between observations and the model results, several statistics with the focus on Hyytiälä station and estimations of total deposition fluxes and deposition on snow over Finland. Section 4 summarizes the results and draws conclusions.

\section{Model description and experiments}

\subsection{REMO-HAM model}

The regional climate model REMO is a hydrostatic, threedimensional atmospheric model developed at the Max Planck Institute for Meteorology in Hamburg and based on the Europa Model, the former numerical weather prediction model of the German Weather Service (Jacob and Podzun, 1996; Jacob, 2001). The physics of the model is derived from the global circulation model ECHAM4 (Roeckner et al., 1996), although many parts have been changed due to higher resolution. Moreover, the model has been updated so that the physics is partly based on ECHAM5 (Roeckner et al., 2003; Pietikäinen et al., 2012). The model has 31 vertical levels and the horizontal resolution used was $0.44^{\circ}\left(50 \times 50 \mathrm{~km}^{2}\right)$.

Pietikäinen et al. (2012) implemented the aerosol module HAM-M7 to the REMO model. HAM-M7 is an aerosol chemistry and physics module, which predicts the evolution of an ensemble of microphysically interacting internally and externally mixed aerosol populations as well as their size distributions and compositions (Vignati et al., 2004). The size distribution is represented by a superposition of seven log-normal modes: one soluble nucleation mode, together with soluble and insoluble aitken, accumulation and coarse modes. The M7 microphysical core includes coagulation, condensation of sulphuric acid gas, nucleation and thermodynamical equilibrium with water vapor, and redistributes the particle mass and number between modes (Stier et al., 2005). The aerosol components considered in HAM-M7 are sulphate (S), black carbon (BC), particulate organic carbon (POM), sea salt (SS) and mineral dust (DU). Table 1 summarizes the way HAM-M7 treats different species and how the aerosol components are divided between different modes. Black carbon is defined in soluble and insoluble Aitken modes and in soluble accumulation and coarse modes. The aging is achieved via condensation of sulphuric acid and coagulation with soluble particles. When condensation of sulphate forms a soluble monolayer on the surface of the hydrophobic BC aerosols, they are moved from insoluble to soluble/mixed mode (Vignati et al., 2004). Similarly for coagulation, when a soluble mode particle coagulates with an insoluble one, the resulting particle is assumed to be soluble. Within the soluble and insoluble modes, the growth of particles can lead to inter-modal transfer (Stier et al., 2005). The aerosol module has been coupled with a stratiform cloud scheme, but so far it has not been coupled with radiation (Pietikäinen et al., 2012).

$\mathrm{BC}$ (and other species) undergoes different transport processes in the model: transport in convective clouds, dry and wet deposition, sedimentation, vertical diffusion and vertical and horizontal advection (Stier et al., 2005; Pietikäinen et al., 2012). The convective transport of tracers is based on the mass-flux scheme by Tiedtke (1989) with modifications by Nordeng (1994). The dry deposition is built on the same size-dependent parameterization as in the ECHAM5-HAM. Wet deposition is based on the modelled precipitation formation rate. The aerosol partitioning between air and cloud water is determined as a function of a size- and compositiondependent scavenging parameter. This parameter is different for stratiform and convective clouds, and it takes into account the mode (size) and hygroscopicity of aerosols (soluble/insoluble) (for more details, for example the scavenging parameter values, see Stier et al. (2005)). Below-cloud scavenging is based on a physically detailed aerosol and collector droplet-size-dependent parameterizations for rain and snow by Croft et al. (2009). They showed that the size-dependent treatment of below-cloud deposition had fairly small impact 
on the $\mathrm{BC}$ concentrations over Europe. The sedimentation velocity calculation is based on the Stokes velocity with the Cunningham slip-flow correction factor accounting for noncontinuum effects (Stier et al., 2005). The sub-grid scale vertical diffusion fluxes are calculated according to Louis (1979) for the lowest level. For other levels, the model uses a second-order closure scheme of hierarchy level 2 by Mellor and Yamada (1974). The horizontal and vertical advection is solved with a finite difference, antidiffusive scheme by Smolarkiewicz $(1983,1984)$.

REMO's transport properties have been evaluated in a series of studies for various trace species. For instance, Chevillard et al. (2002a) compared the simulations of ${ }^{222} \mathrm{Rn}$ from REMO and global model TM3 with continuous observations across Europe, showing that REMO reproduces well the transport features on a synoptic and subsynoptic scale, often performing better than TM3. In an accompanying study, Chevillard et al. (2002b) investigated the spatial distribution and temporal variability of atmospheric $\mathrm{CO}_{2}$ over Europe and Western Siberia using REMO. The model results were compared to continuous measurements at ground stations and vertical profiles from aircraft measurements, concluding that REMO realistically simulates the short-term variability of $\mathrm{CO}_{2}$ fluxes and mixing ratios. REMO has been used to investigate the distribution and spatiotemporal variability of $\mathrm{CO}, \mathrm{CO}_{2}$ and ${ }^{14} \mathrm{CO}_{2}$ (Gamnitzer et al., 2006), the summer smog episodes in Europe (Langmann et al., 2003) and the dispersion of particulate matter originating from peat fires in Asia (Langmann and Heil, 2004), all reporting good results.

Based on the evalution of Pietikäinen et al. (2012), the current REMO-HAM version is missing at least two important physical features: an online coupled radiation module and a secondary organic aerosol module. The first deficiency links the modelled aerosols directly to the climate - which can induce various effects to $\mathrm{BC}$ concentrations, especially on local scales - while the latter has direct impact on aerosol concentrations and composition, which can lead to changes in $\mathrm{BC}$ concentrations.

The emissions used in the present study are based on the AEROCOM emission inventory for the year 2000 (http: //nansen.ipsl.jussieu.fr/AEROCOM/), except for the sea salt and dimethyl sulphide (DMS) emissions which are based on an approach by Stier et al. (2005). BC emissions originate from three different sources: vegetation fires, usage of fossil fuels and usage of biofuels. All black carbon emissions are released to the insoluble Aitken mode. A detailed list of other different emission species and sources is presented in Dentener et al. (2006). The model domain covering the entirety of Europe is presented in Fig. 1. The colour scheme represents the modelled yearly mean black carbon concentration. On average, the concentrations near the strongest emissions sources in Europe are about one order of magnitude higher than in southern Finland and almost two orders of magnitude higher than in Lapland.

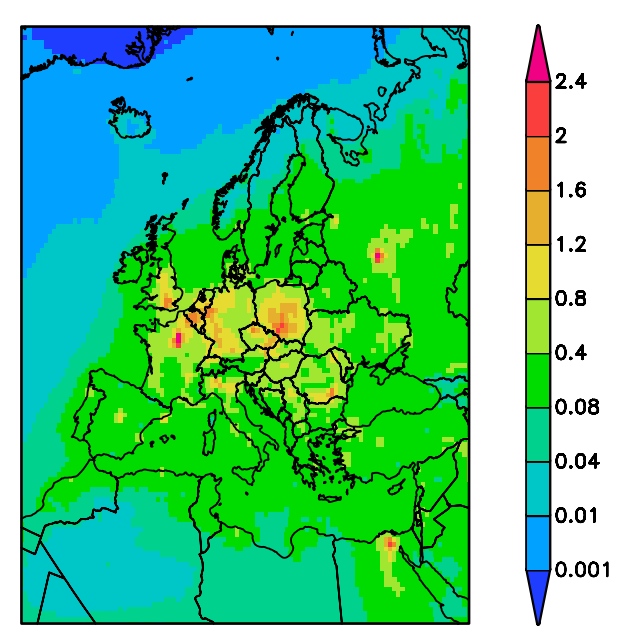

Fig. 1. The model domain covers the entirety of Europe. The colour scheme represents the modelled yearly mean black carbon concentrations $\left[\mu \mathrm{g} / \mathrm{m}^{3}\right]$.

The lateral and upper boundary treatment in REMO-HAM is similar to the one described in Pietikäinen et al. (2012): the European Center for medium-Range Weather Forecast (ECMWF) operational dataset was used for the lateral meteorological boundary data with the relaxation scheme by Davies (1976), while the aerosol boundary data were obtained from ECHAM5-HAM run in nudged mode with ECMWF analysis data. The spin-up times were three months for ECHAM5-HAM and two months for REMO-HAM.

AEROCOM is one of the most used emission inventories, especially by the aerosol simulation community. It comprises a compilation of emissions dedicated to help the hindcast of aerosol simulation, and it includes Bond et al. (2004) emissions for BC. It has to be noted that AEROCOM does not include the residential wood burning which, according to Kupiainen (2006), accounts for 25-30\% of the total emissions in Western Europe. Granier et al. (2011) compared a series of global and regional anthropogenic and biomass burning emission inventories for the period 1980-2010. For BC in particular, 12 emission inventories were assessed, including AEROCOM, Bond (Bond et al., 2007), GAINS (Kupiainen and Klimont, 2007; Klimont et al., 2009; Cofala et al., 2007), and ACCMIP (Lamarque et al., 2010). Despite the large discrepancies found between the emission inventories until mid-1990, the authors report a better agreement for the year 2000 in terms of $\mathrm{BC}$ anthropogenic emissions at global scale, with a maximum difference of $22 \%$, and with an even better consensus of $20 \%$ for Western Europe. However, much larger differences (a factor of two) were found for Central Europe. Although the differences are not insignificant, they are within the uncertainty range estimated in Bond et al. (2004). AEROCOM inventory shows an increase of about $10 \%$ in the global anthropogenic emissions of $\mathrm{BC}$, from about $4.8 \mathrm{Tg} \mathrm{yr}^{-1}$ in 2000 to $5.2 \mathrm{Tg} \mathrm{yr}^{-1}$ in 2005 
(Fig. 1a in Granier et al. (2011)). However, the emissions for Western and Central Europe remain rather constant after the year 2000 (Fig. 2a, b in Granier et al. (2011)). As such, the emissions for the year 2000 can be used for the year 2005 without introducing significant errors. As such, AEROCOM became our emission inventory of choice for this study in order to have a common ground with other studies and to allow future comparisons with different models using the same dataset as input. An ongoing REMO-HAM project deals with new, country-specific emission inventory and will be published within months. However, this is not within the scope of the present study.

Pietikäinen et al. (2012) evaluated the REMO-HAM model in terms of aerosol number concentration, size distribution and gas phase sulphur dioxide concentrations by comparing the model results with ECHAM5-HAM and measurement data for four different sites for the year 2005 using AEROCOM emission inventory for 2000. According to the authors, REMO-HAM was able to represent the measured values well, showing also a slight improvement from ECHAM5HAM. As such, in the present study we focus only on black carbon, as a step towards the overall model evaluation.

\subsection{Experimental data}

The measurements were conducted at five different locations in Finland:

1. Pallastunturi GAW (Global Atmosphere Watch) station (Hatakka et al., 2003), a remote station located in the subarctic region at the limit of the northern boreal forest zone;

2. Hyytiälä SMEAR II (Station for Measuring Forest Ecosystem - Atmosphere Relations) station (Kulmala et al., 2001; Hari and Kulmala, 2005), a rural station in southern Finland, representative of boreal forest;

3. Puijo SMEAR IV station (Leskinen et al., 2009), located in the suburb of Kuopio (population 91000 );

4. Utö EMEP (European Monitoring and Evaluation Programme) station (Engler et al., 2007), situated on a small island about $60 \mathrm{~km}$ from the Finnish southwest coast and $90 \mathrm{~km}$ from the city of Turku (population 176 000);

5. and Virolahti EMEP station (Anttila et al., 2008), located in the south-eastern corner of Finland, with the Russian border $6 \mathrm{~km}$ to the east and E18 highway $5 \mathrm{~km}$ to the north.

The measurement sites and instruments have been described in detail by Hyvärinen et al. (2011) and their locations are presented in Fig. 2. The colour scheme in the figure depicts the black carbon annual emissions in the model domain.

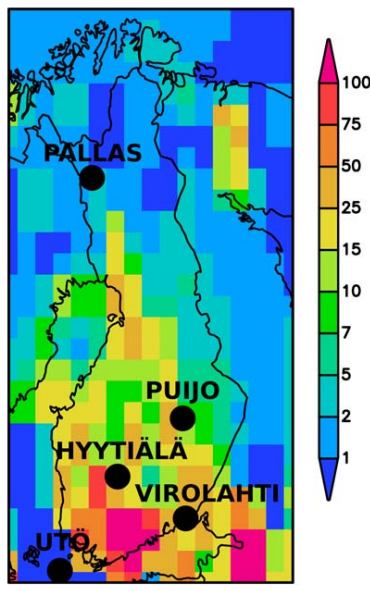

Fig. 2. The location of the measurement stations in Finland. The colour code represents the yearly black carbon emissions $\left[\mathrm{mg} / \mathrm{m}^{2}\right]$.

The black carbon measurements were conducted with two different instruments: the AE 31 aethalometer (Magee Scientific) and the multi-angle absorption photometer (MAAP) (Thermo Scientific). As BC by definition cannot be unambiguously measured with these instruments, it is customary to refer to the measured light-absorbing constituent as equivalent BC. As both the aethalometer and MAAP utilize a light absorbance method on a filter strip, they yield very comparable data of the aerosol BC, as was found at Pallastunturi (see the Supplement in Hyvärinen et al. (2011)).

The measurement details of $\mathrm{BC}$ from each station are specified in Table 2. The concentrations measured behind different inlets are comparable as long as there are no sources of black carbon from, e.g., incomplete combustion (Hyvärinen et al., 2011). The time resolution of the instruments was typically one minute. Five-minute average data were qualitychecked and data with outliers or instrument problems were removed. More than 20 minutes of data coverage was required for the computation of hourly averages.

Additional uncertainty between the modelled and measured $\mathrm{BC}$ concentrations may arise from the fact that the measurements provide optically defined $\mathrm{BC}$ concentrations, whereas the model actually deliver mass-based elemental EC rather than $\mathrm{BC}$. $\mathrm{BC}$ and $\mathrm{EC}$ are two carbon fractions typically defined by their measurement technique: $\mathrm{BC}$ is measured optically while EC is obtained from thermal and thermaloptical methods. According to the EPA Report to Congress on Black Carbon (http://www.epa.gov/blackcarbon/), about $70 \%$ of recent studies (year 2000 or later) that compared ambient BC and EC measurements in a wide variety of environments reported consistently obtaining a high correlation with an average of $R=0.86 \pm 0.11$ (Allen et al., 1999; Bae et al., 2007; Hitzenberger et al., 2006; Sahu et al., 2009; Miyazaki et al., 2008; Husain et al., 2007; Hagler et al., $2007)$, while the other $30 \%$ report very low BC: EC ratios $(\sim 0.5)$ and very high BC: EC ratios $(\sim 2)$ (Chow et al., 2009; 
Table 2. Measurement details for each station.

\begin{tabular}{lllll}
\hline Station & Instrument & Inlet & $\begin{array}{l}\text { Inlet height } \\
\text { (ground/sea level) }\end{array}$ & $\begin{array}{l}\text { Measurements } \\
\text { started }\end{array}$ \\
\hline Pallastunturi & Aethalometer AE 31* & $\begin{array}{l}\text { Gas line, } \\
\text { total air }\end{array}$ & $7 \mathrm{~m} / 572 \mathrm{~m}$ & $\begin{array}{l}\text { 18 Aug 2005 } \\
\text { 07 Jan 2008 }\end{array}$ \\
\cline { 2 - 5 } & MAAP & $\mathrm{PM}_{10}$ & $7 \mathrm{~m} / 572 \mathrm{~m}$ & 04 Sep 2007 \\
\hline $\begin{array}{l}\text { Hyytiälä } \\
\text { Puijo }\end{array}$ & Aethalometer AE 31 & $\mathrm{PM}_{10}$ & $4 \mathrm{~m} / 179 \mathrm{~m}$ & 08 Dec 2004 \\
$\begin{array}{l}\text { Utö } \\
\text { Virolahti }\end{array}$ & MAAP & $\mathrm{PM}_{2.5}$ & $75 \mathrm{~m} / 306 \mathrm{~m}$ & 25 Aug 2006 \\
$\mathrm{PM}_{2.5}$ & $\begin{array}{l}2 \mathrm{~m} / 7 \mathrm{~m} \\
2 \mathrm{~m} / 4 \mathrm{~m}\end{array}$ & 26 Jan 2007 \\
& Aethalometer AE 31 & $\mathrm{PM}_{2.5}$ & 2006 \\
\hline
\end{tabular}

* In the total air inlet since 7 Jan 2008. Gas line inlet has a cut-off size of about $7 \mu \mathrm{m}$. Total air inlet has no cut-off, and has heating for drying the aerosol.

Babich et al., 2000; Jeong et al., 2004; Lim et al., 2003). These inter-comparison data are based on ambient measurements and not on source measurements. The BC (or EC) in the emission inventories are not directly measured, but calculated mathematically from $\mathrm{PM}_{2.5}$. In such cases we acknowledge the fact that the difference between BC and EC may increase the scatter and/or bias between the measurements and simulations, but without actual measurements at the sites the magnitude of the scatter or bias is difficult to quantify.

\section{Results}

To characterize the REMO-HAM's abilities and limitations, the model results calculated for the year 2005 are compared with experimental data. This study uses observations from five sites for different periods of time as specified in Table 2. For each site we used the first full year with available data. According to Hyvärinen et al. (2011), BC concentrations exhibited each year a clear seasonal cycle with the highest concentrations during the spring and winter, and the lowest during the summer. In addition, the year-to-year variation of the annual average BC levels is not larger than $20 \%$ for all stations, although few individual months exhibited larger differences. As such, the comparison of the 2005 model run with different years of experimental data should be regarded as qualitative rather that quantitative in nature. Because Hyytiälä station had black carbon measurements for the entirety of 2005, the analysis and the comparison will focus on this station only, while for the others we will just briefly summarize the findings. However, it is expected that the model-measurement differences in Puijo, Utö, Virolahti and Pallastunturi mostly have the same causes as in Hyytiälä.

The BC concentration measurements are confined to a point in space, while the model gives the parameter over an area defined by the model's grid box. However, since the resolution used in REMO is $0.44^{\circ} \times 0.44^{\circ}\left(50 \times 50 \mathrm{~km}^{2}\right)$ and there are no major point sources within the grid cells where the measurement sites are located (Williams et al., 2011), we can consider that the point measurement is representative for the entire grid cell. The $\mathrm{BC}$ concentrations at a given location were calculated using the CDO (Climate Data Operators) remapping tools, that is, a bilinear interpolation to a one-point grid in which the coordinates (latitude and longitude) have been defined. A detailed description of CDO can be found at https://code.zmaw.de/projects/cdo.

\subsection{BC concentrations: model vs. measurements}

The surface mass concentrations of black carbon were examined first. The monthly means of modelled and measured black carbon concentration for the 5 station are shown in Fig. 3. A seasonal variation is detected for all the stations, with a maximum in late winter/early spring and a second maximum in the autumn, potentially due in part to lower mixing height levels during this time of the year. Lower $\mathrm{BC}$ concentrations during the summer are probably due to slightly lower traffic, less biomass burning and better dilution because of the higher mixing height. The model was able to reproduce the seasonal cycle, with better agreement with the measured values outside of the periods of maximum observed $\mathrm{BC}$ concentrations (see the relevant numbers for each site below).

At Hyytiälä, the observed monthly mean concentrations ranged from 175 to $687 \mathrm{ng} \mathrm{m}^{-3}$, while the modelled monthly means ranged from 100 to $334 \mathrm{ng} \mathrm{m}^{-3}$. REMO underestimated the observations significantly during the winter and autumn maxima by more than $50 \%$. During early spring and summer, the disagreement between REMO results and observations was still quite high, with an average underestimation of roughly $40 \%$.

The highest monthly averaged concentrations measured in Pallas were $160 \mathrm{ng} \mathrm{m}^{-3}$ during February and $143 \mathrm{ng} \mathrm{m}^{-3}$ during March. The autumn maximum was less pronounced in comparison to the other locations. REMO seriously underestimated the observations during July-September, when modelled BC was about $20 \%$ of the measured BC. The model overestimated the observations during October by $22 \%$. 

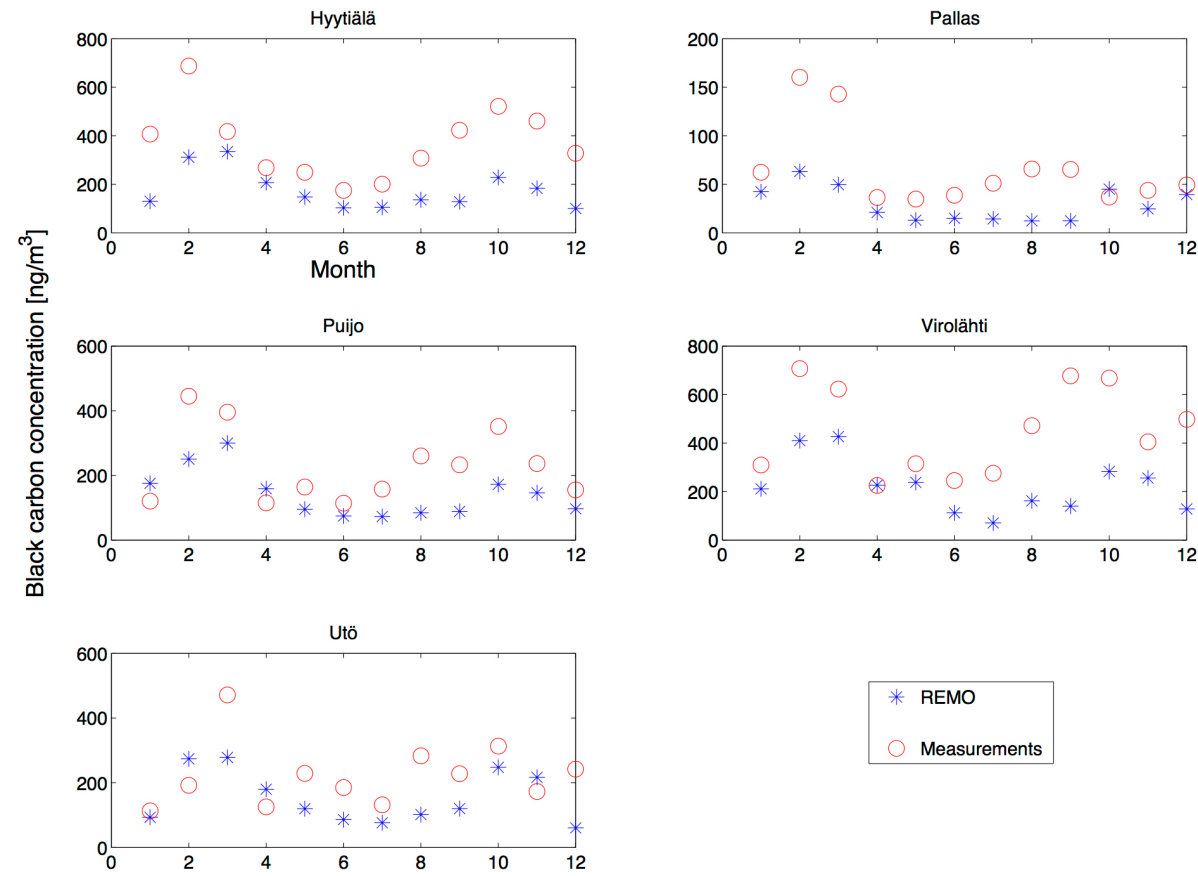

Fig. 3. Monthly average of black carbon concentrations (red circles represent the measurements and the blue stars the model result for the year 2005).

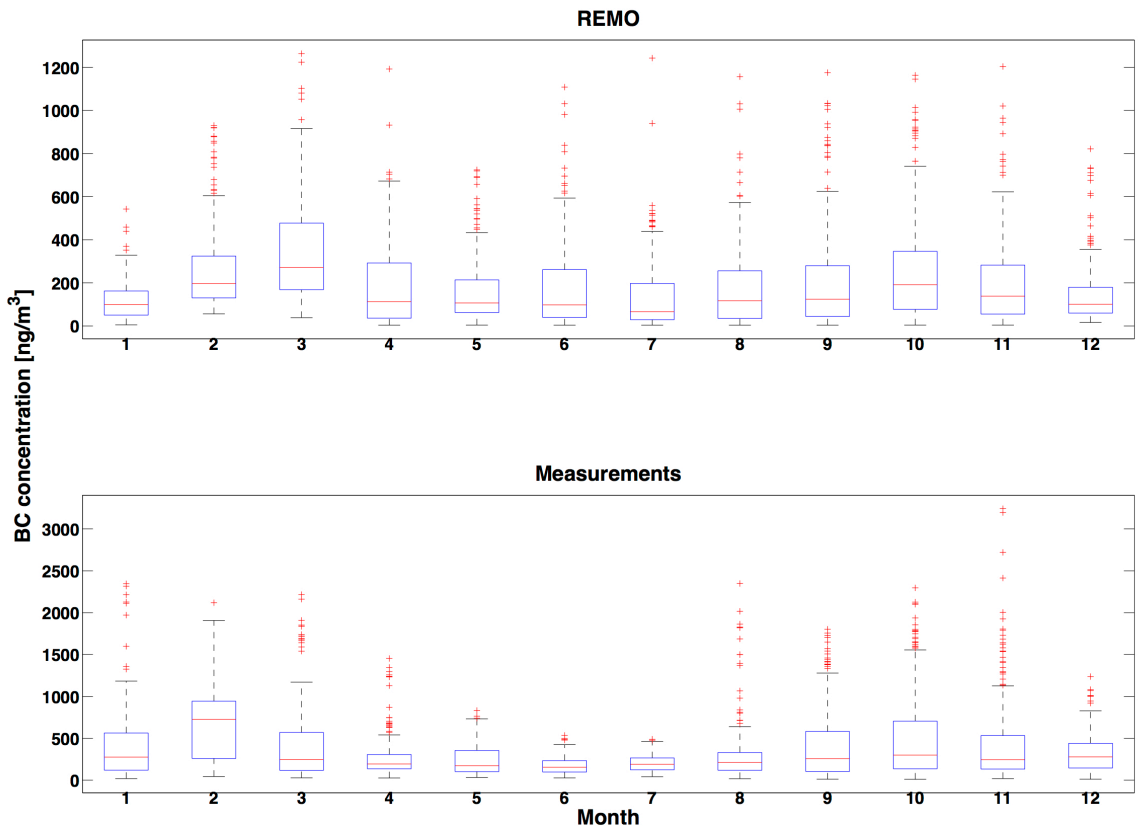

Fig. 4. The box-and-whisker diagram of the model (upper panel) and measurements' (lower panel) BC concentrations in Hyytiälä (2005). The solid red line locates the median, the edges of the box are the 25th and 75th percentiles and the red plus marks represent the outliers.

At Puijo, the measured monthly average concentrations were in the range of $114-445 \mathrm{ng} \mathrm{m}^{-3}$. REMO underestimated the observed monthly averages by $31 \%$, the largest differences being seen in August $(67 \%)$ and September $(61 \%)$.
The BC experimental monthly means in Virolahti varied from 225 to $707 \mathrm{ng} \mathrm{m}^{-3}$. The corresponding range was simulated by REMO as $70-426 \mathrm{ng} \mathrm{m}^{-3}$. On average, REMO underestimated the observations by $47 \%$. 
The measurements at Utö showed a clear maximum in March, which was not captured by the model. However, REMO reproduced the measurements quite well for most of the months, with the exception of August and December, when the differences between the model results and observations were considerable. The underestimation of the model was $47 \%$ for spring and summer, while for winter and autumn months the underestimation was about $20 \%$.

Overall, a systematic underestimation of calculated black carbon concentrations was detected for all stations, with pronounced problems during February and March, followed by less pronounced discrepancies during the autumn. In addition, the measured black carbon concentrations give a clear picture of the $\mathrm{BC}$ levels in different parts of the country, with low BC concentrations in Lapland and about 3-4 times higher levels in central and southern Finland. The model follows the north-south gradient of $\mathrm{BC}$ concentrations quite well.

\subsection{Case study: Hyytiälä}

\subsubsection{Statistics}

Figure 4 depicts the box-and-whisker monthly diagram of 3hourly resolution data of modelled (upper panel) and measured (lower panel) black carbon concentrations. In each box, the central solid red line locates the median, the edges of the box are the lower and upper quartiles (25th and 75th percentiles), the whiskers stretch to the most extreme data points that were not considered outliers, and outliers are shown individually (red plus mark). The REMO outliers were relatively evenly distributed, except for January and May, while the measurements showed more variability in the extreme values. Both REMO and measurement monthly data were positively skewed (with long upper whiskers and a large number of outliers towards larger values), showing a strong departure from the normal Gaussian curve. As such, the use of median instead of mean makes more sense for comparing the time series of the model and the measurements. The same figure shows distinctly different upper extreme values, or, in other words, different concentration ranges. The REMO concentrations went up to about $1200 \mathrm{ng} \mathrm{m}^{-3}$, while the measurements reached values up to $3000 \mathrm{ng} \mathrm{m}^{-3}$.

For further comparison, the monthly medians are presented in Fig. 5. The highest measured monthly median value appeared in February, which was about 2-3 times higher than observed during the rest of the months. This pattern is consistent with other measurements made in Hyytiälä during 20062008 presented in Hyvärinen et al. (2011) (Fig. 3, panel 3 in their article), except for 2008 when the median BC concentration peaked in March. The largest discrepancy between the model and the measurements was also recorded in February, with a modelled median BC concentration being about 3.5 times smaller than the measured median. On the other hand, March and September showed the best agreement between

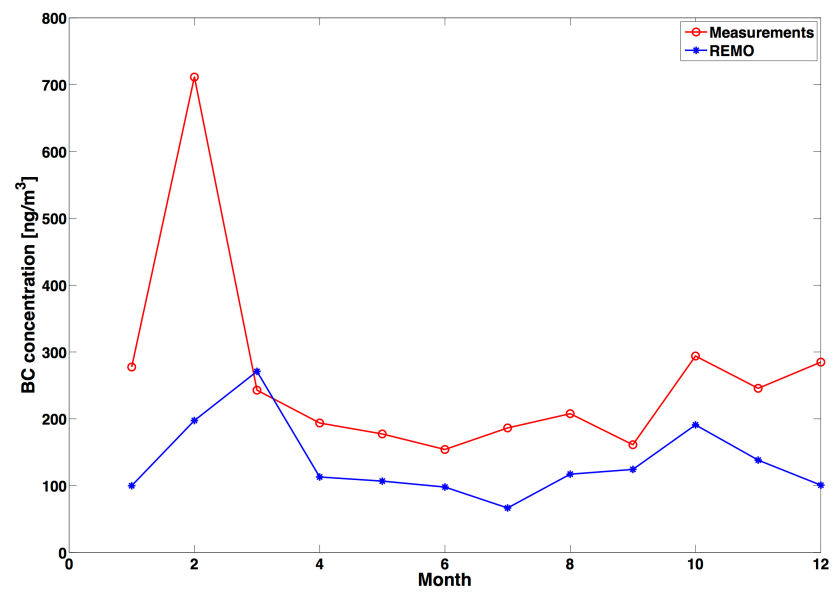

Fig. 5. Monthly medians of the black carbon concentrations, where the red circles represent the measurements and the blue stars the model results (Hyytiälä, 2005).

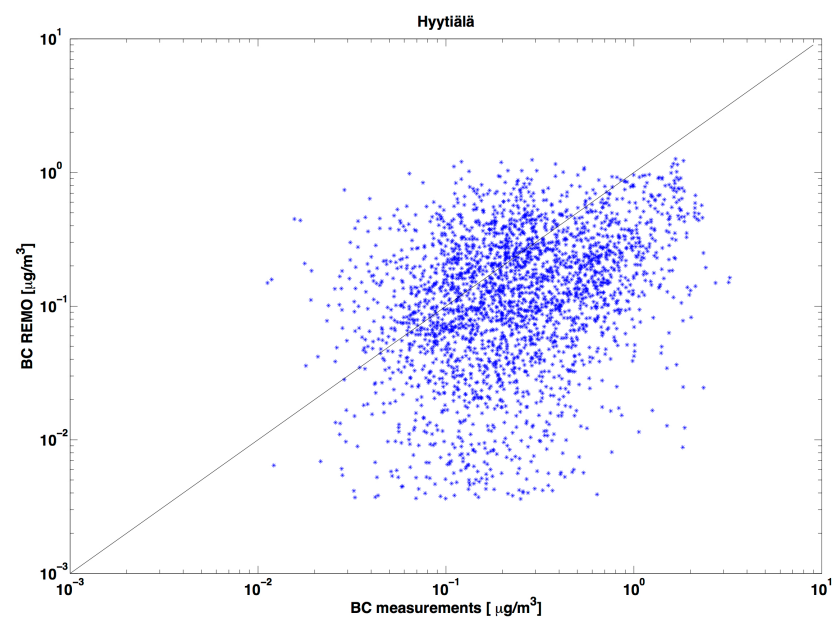

Fig. 6. 3-hourly scatter plot of the black carbon concentrations in Hyytiälä (2005): model vs measurements.

the model and the measurements in terms of medians, while for the rest of the months the simulated values were within a factor of 2 of the corresponding measured values.

The scatter plot of $3 \mathrm{~h}$ resolution data for the entire period presented in Fig. 6 gives a good visual picture of the correspondence between the two sets of data. The model underestimate is evident. It is difficult to point out a specific reason for this underestimation. However, the February case seems to be a local feature, where the probable cause is the existence of a point BC source not accounted for in the model's emission inventory. The local emissions affect BC concentrations on short time scales and consequently induce larger variabilities of observations as compared to model simulations.

The use of a single statistic (like median) to gauge the quality of the model is usually insufficient. In order to asses 


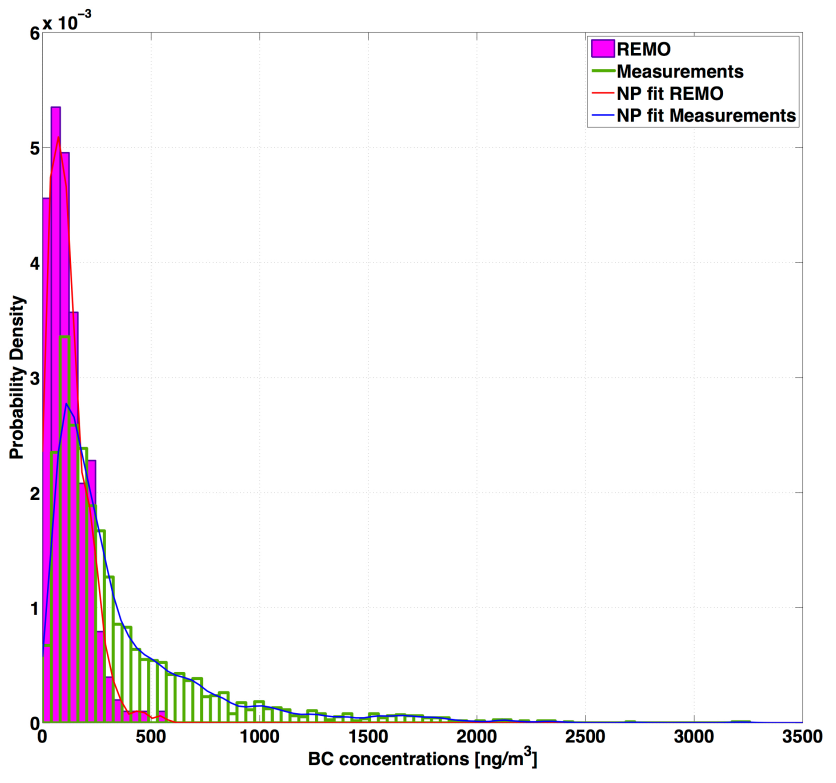

Fig. 7. The histograms (pink: REMO; and green: measurements) and the probability density functions (pink: REMO; and blue: measurements) of the black carbon concentration for the entire experimental period (Hyytiälä, 2005).

the agreement between the model and the observations, several other statistical tools should be considered. For instance, the overlap coefficient $\left(\mathrm{OVL}^{*}\right)$, defined as the common area under two probability distributions curves, offers a technique for exploring the discrepancies between two samples and provides a good measure of the agreement between the distributions. In general, this area is defined as

$\mathrm{OVL}^{*}=\int_{-\infty}^{\infty} \min \left[f_{1}(X), f_{2}(X)\right] d X$,

where $f_{1}(X)$ and $f_{2}(X)$ are the probability density functions of the two distributions (Clemons and Bradley Jr., 2000). In our case, the overlap coefficient is calculated by dividing $\mathrm{OVL}^{*}$ by the area under the measurements' probability density function (PDF), resulting in a fraction (or percentage, respectively, if multiplied by 100) of the measurements that are covered by the model. Henceforth, this fraction will be denoted by OVL. OVL ranges from $0-$ when the distributions are completely distinct - to 1 , when the distributions are identical. Like any other statistical tool, OVL has its own advantages and disadvantages. On the plus side, OVL is a simple, easy-to-understand concept, as well as being less restrictive than other methods in the sense that the measurement of the agreement between the distributions can be done no matter what the distribution setting is. The disadvantage of using OVL lies in the fact that its magnitude does not denote where the common area is located.
Our distributions were positively skewed, and therefore a reasonable parametric form to characterize them was hard to deliver. As such, we considered a nonparametric approach, in the form of a kernel density estimator. Fig. 7 depicts the histograms and the nonparametric density functions for the measured and computed 3-hourly resolution black carbon concentrations for Hyytiälä over the entire year of 2005. The bin widths, BW, (and consequently the number of bins) for the histograms were calculated using the Freedman-Diaconis rule (Freedman and Diaconis, 1981) which states that

$\mathrm{BW}=2 \operatorname{IQR}(x) n^{-1 / 3}$,

where IQR represents the interquartile range of the data and $n$ is the number of observations in the sample $x$. The model distribution data was narrow and shifted towards smaller concentrations, whereas the measurement distribution had a long tail towards higher concentrations. In this case, the overlapping coefficient was 0.59 , showing that nearly $60 \%$ of the observed data could be explained by the model. However, the model failed to simulate concentrations higher than about $500 \mathrm{ng} \mathrm{m}^{-3}$ and underestimated the concentrations between 250 and $500 \mathrm{ng} \mathrm{m}^{-3}$ by more than $50 \%$. For very low concentrations the model overestimated the observations significantly.

More information about REMO-HAM behaviour can be obtained by exploring the monthly density functions presented in Fig. 8 together with the monthly overlap of the probability density curves (blue) shown in Fig. 9. In terms of the overlap coefficient, the poorest agreement between REMO and measurements was observed in February, with an OVL less than 0.4 - as expected from the median comparison in Fig. 5 - while for the rest of the months the agreement was constantly above 0.5 . The highest overlap values were registered in March and September with values above 0.8 , followed by May, October and November with OVLs between 0.7 and 0.8 . In terms of seasons, the model was able to explain $76 \%$ of the observed data for autumn, $72 \%$ for spring, $59 \%$ for summer and only $48 \%$ for winter. There was no seasonal pattern associated with the overlap coefficient.

The Mann-Whitney $U$ test is the nonparametric equivalent of, and has a similar statistical power as, the independent samples $t$ test. It is used when the sample data are not normally distributed. The Mann-Whitney $U$ test is applied to the $3 \mathrm{~h}$ resolution data from the measurements $(M)$ and $\operatorname{REMO}(R)$ and calculated for each month (12 sets in total). First, the data were combined into a set of $N=N_{M}+N_{R}$ elements (the number of measurement and REMO data points, each ranging between 224 and 248, depending on the length of the month), then ranked from lowest to highest BC concentration magnitude, including tied rank values where appropriate. Tied rank value represents the average of the ranks that two or more identical scores would have obtained, had they be different from each other. The rankings were resorted into the two separate samples R and M, and the sum 


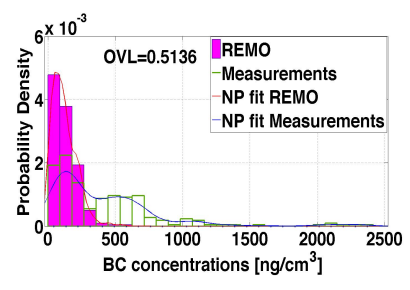

(a) January

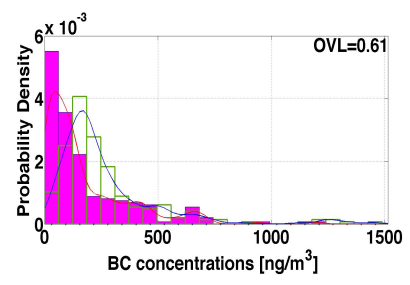

(d) April

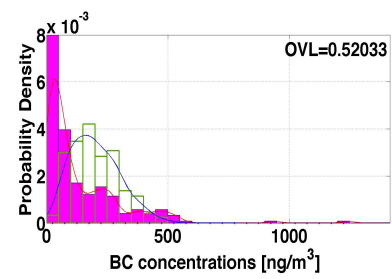

(g) July

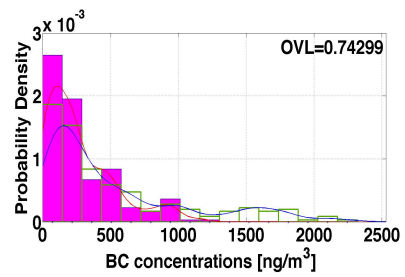

(j) October

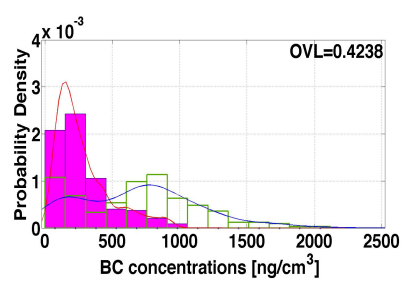

(b) February

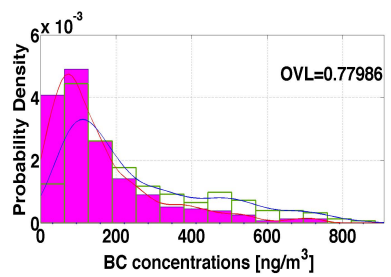

(e) May

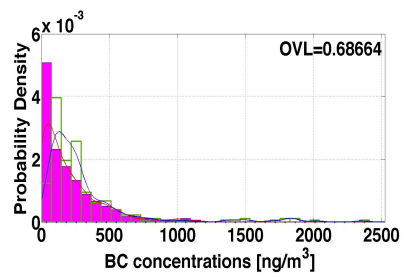

(h) August

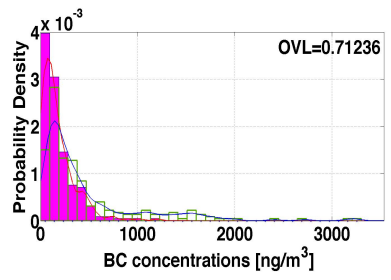

(k) November

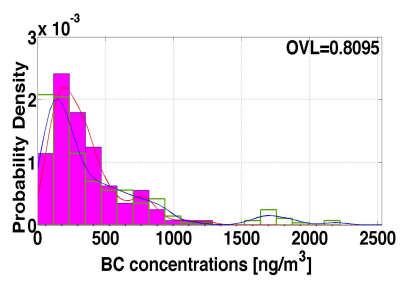

(c) March

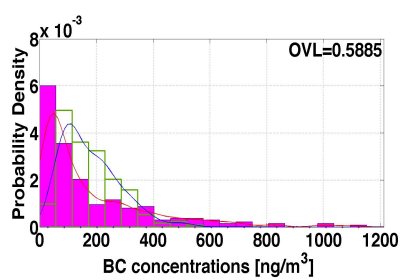

(f) June

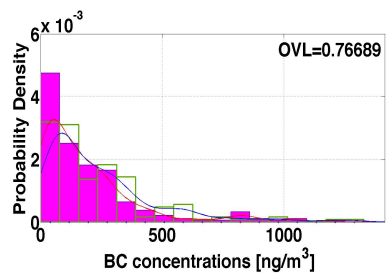

(i) September

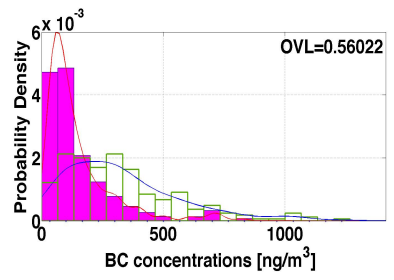

(1) December

Fig. 8. Monthly histograms (pink: REMO; and green: measurements) and the probability density functions (pink: REMO; and blue: measurements) of the black carbon concentration (Hyytiälä 2005). The overlap coefficient (OVL) for each month is listed in the upper part of each plot.

of the ranks of each sample $\left(S_{\mathrm{R}}\right.$ and $\left.S_{\mathrm{M}}\right)$ was calculated. The Mann-Whitney $U$ statistic is given by

$U=\min \left(U_{\mathrm{M}}, U_{\mathrm{R}}\right)$,

where the $U$ statistic for each sample is

$U_{i}=S_{i}-\frac{N_{i}\left(N_{i}+1\right)}{2}$,

with $i=\mathrm{R}, \mathrm{M}$. For a large sample $(N>20), U$ is approximately normally distributed and the standardized value or the $\mathrm{Z}$ score (or coefficient) can be calculated as

$Z=\frac{\left|\frac{N_{\mathrm{R}} N_{\mathrm{M}}}{2}-U\right|}{\sigma}$, where $\sigma$ is the standard deviation given by

$\sigma=\sqrt{\frac{N_{\mathrm{R}} N_{\mathrm{M}}(N+1)}{12}}$.

In case two or more data are the same, the normal approximation still can be used with an adjustment to the standard deviation,

$\sigma=\sqrt{\frac{N_{\mathrm{R}} N_{\mathrm{M}}}{N(N-1)}\left[\frac{N^{3}-N}{12}-\sum_{j=1}^{g} \frac{t_{j}^{3}-t_{j}}{12}\right]}$,

where $g$ is the number of groups of ties and $t_{j}$ is the number of tied ranks in group $j$. 


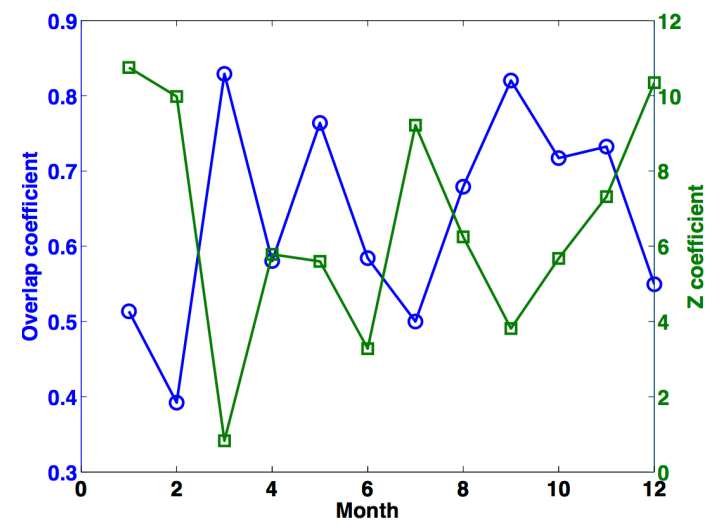

Fig. 9. Monthly overlap coefficient (OVL) and Z coefficient.

The Z score (presented in Fig. 9) is a measure of standard deviation, but also a test of statistical significance that helps to decide whether or not to reject the null hypothesis. The null hypothesis is in principle a hypothesis of "no difference". Very high Z scores are usually found in the tail of a distribution, indicating that the null hypothesis is very unlikely. In our case, large values of $\mathrm{Z}$ were associated with poor agreement between the observations and the model results. According to Fig. 9, only one $\mathrm{Z}$ value was below the usually agreed critical $\mathrm{Z}$ score value of 1.96 (corresponding to $95 \%$ confidence level), that is, in the case of March, which also corresponds to a large overlap coefficient. This is the only case when we can not reject the null hypothesis. The $\mathrm{Z}$ scores for the rest of the months ranged from 2.5 to 12 , indicating that a rejection of the null hypothesis is possible. As expected, the $\mathrm{Z}$ score and the overlap coefficients were anticorrelated. However, in some cases, a relatively high OVL was characterized also by high $Z$ values (see May, August, October and November). The highest $Z$ scores (above 9) were found for January, February, July and December and were related also to clearly different shapes of the model and measurement distribution curves. According to Hart (2001), the Mann-Whitney test (and the related Z score) can detect not only the differences in medians but also the differences in shapes and spreads.

\subsubsection{Wind direction and black carbon concentrations}

In order to determine the wind direction conditions contributing to the highest $\mathrm{BC}$ concentration levels in Hyytiälä, the black carbon concentrations were categorized by wind direction. Hourly wind direction data for Hyytiälä were obtained from http://www.atm.helsinki.fi/ junninen/ smartSearch (Junninen et al., 2009) and then combined on a $3 \mathrm{~h}$ basis to match the corresponding modelled data. Fig. 10 presents the wind rose diagrams and the associated measured BC concentrations for each season. The length of the slices represents the percentage of time the wind blows from a certain direction, and the colour diagram represents the $3 \mathrm{~h} \mathrm{BC}$ average mass concentration. The prevailing wind direction was from the south. However, the diagram indicates that the major black carbon contribution came from south-east and south-south-east corridors which were also associated with low wind speeds (not shown). These directions hint at Orivesi as the dominant source. Orivesi is a typical Finnish town, with a population of approximately 10000 , located $20 \mathrm{~km}$ from Hyytiälä, consisting mostly of houses, with no significant industrial activity. In such towns, the residential wood burning is considerable all around the year, a BC source usually overlooked in the (global) emission databases.

The second-highest concentrations of black carbon came from the the southwest sector, mostly evident in autumn, but less distinct during spring and winter. A possible source in this direction is Tampere (population of 213 000), the largest inland city in the Nordic countries located about $60 \mathrm{~km}$ from Hyytiälä. Although Tampere is definitely a stronger source of black carbon than Orivesi, the concentrations measured from this direction were smaller, potentially due to the greater distance and to higher wind speed, the latter affecting the $\mathrm{BC}$ concentrations through its dispersive effects.

The modelled wind directions and their associated black carbon concentrations are presented in Fig. 11. Although the model fitted well the measurements during the autumn, the correlation between the model data and the observations in Hyytiälä for the entire year of 2005 was rather low. This is most likely due to the fact that the wind direction measurements represented real local conditions, while the model results were the values from the edges of the grid box of the location. However, the directions of the highest concentrations of black carbon, although not as elevated as in the measurement data, were reproduced fairly well by the model. The exception was found in spring, when elevated measured concentrations of $\mathrm{BC}$ came from south-east and southwest sectors, while the model's main $\mathrm{BC}$ source comes from the north-east and to a lesser extent from the south-east.

In both modelled and measured cases presented above, the black carbon concentrations peaked in the direction of Tampere and Orivesi, showing the contribution of the local emission sources. As such, the much lower modelled concentrations coming from the same directions could be explained by the defective local $\mathrm{BC}$ emission inventories. On the other hand, the long-range-transported $\mathrm{BC}-\mathrm{a}$ topic that will be discussed in the following chapter - is expected to be associated with a much broader wind direction distribution.

\subsubsection{Long-range-transported black carbon}

It is well documented that Finland is subject to longrange transport of polluted air, mostly originating from densely populated areas of Europe (Sogacheva et al., 2005; Aurela et al., 2011). As such, the long-range-transported $\mathrm{BC}$ should also be taken into consideration. To study the model over- and underestimation of $\mathrm{BC}$ concentration, the sources and transport pathways of the air masses arriving at 

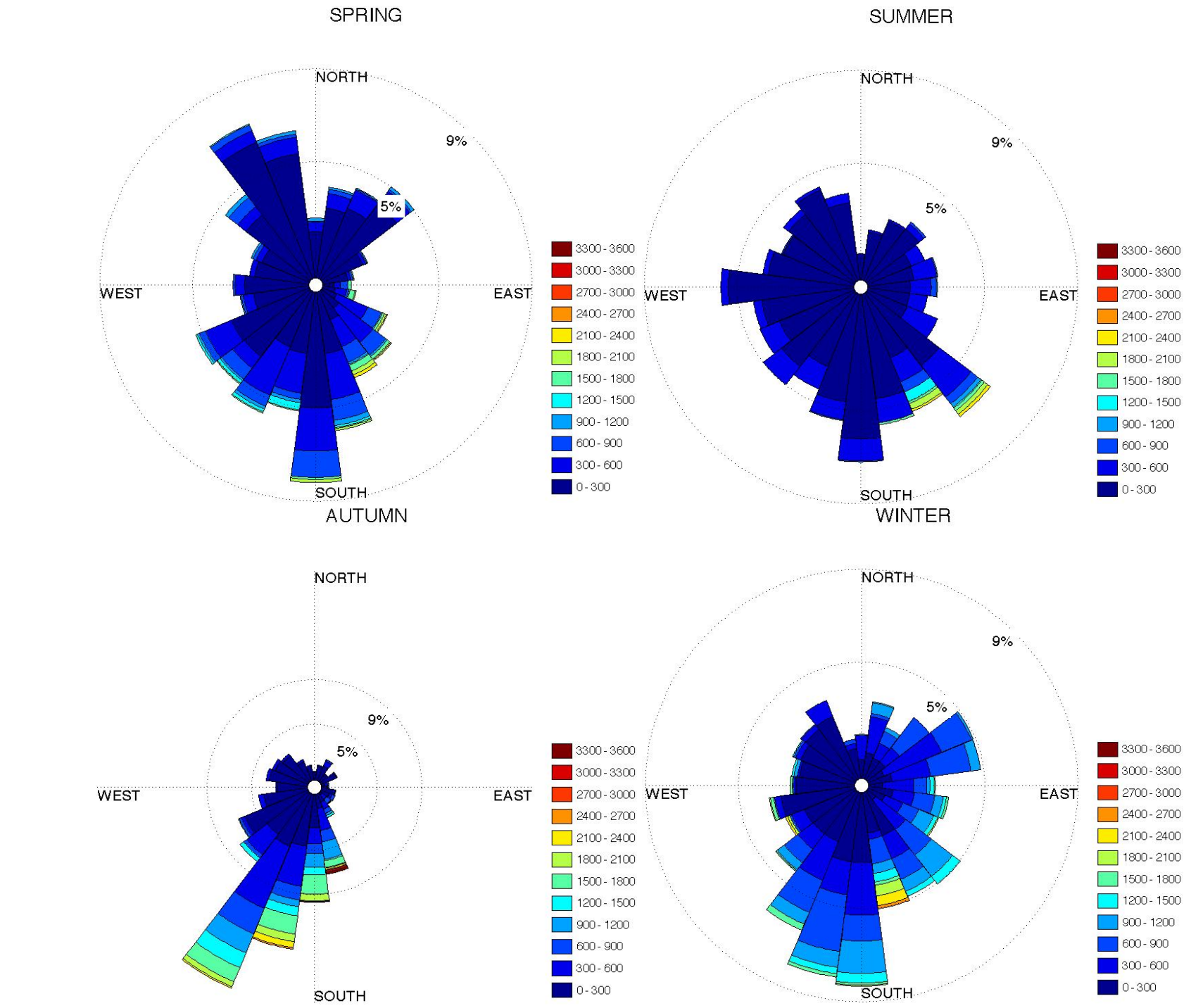

Fig. 10. The measured seasonal wind directions (slices) and BC concentrations represented as a colour scheme (Hyytiälä 2005).

Hyytialä station were analysed using the HYSPLIT-4 (Hybrid Single-Particle Lagrangian Integrated Trajectory) model developed by NOAA Air Resource Laboratory (Draxler and Hess, 1998). The 4-day back trajectories arriving at 12:00 LT at $100 \mathrm{~m}$ height above ground level were calculated. This height was chosen to study the air mass transport inside the boundary layer, to catch all possible emission sources and to eliminate additional errors related to surface topography. The arrival time was chosen to be midday as during wintertime at higher latitudes the boundary layer is considered to be formed by 12:00. The midday calculated trajectories are also representative for the averaged day time trajectories (not shown). Air mass back trajectories were combined seasonally and classified in 3 groups according to the degree of disagreement between measurements and model results: a) REMO-HAM overestimation, b) REMO-HAM moderate underestimation (the maximum difference between observa- tions and model of $300 \mathrm{ng} \mathrm{m}^{-3}$ ) and c) REMO-HAM severe underestimation (the difference above $300 \mathrm{ng} \mathrm{m}^{-3}$ ).

The results for the first case are presented in Fig. 12. Air mass transport through all seasons was mainly from the Arctic and North Atlantic, considered as a clean, lowanthropogenic-emissions area. During the transport to the site, the air masses were not passing over significant sources of $\mathrm{BC}$, and therefore the measured concentrations were low. The overestimation is small to moderate, with an average of $170 \mathrm{ng} \mathrm{m}^{-3}$ and median of $100 \mathrm{ng} \mathrm{m}^{-3}$.

Figure 13 depicts the moderate model underestimation. In this case, the air masses were mainly of Arctic and North Atlantic origin in spring and summer and only a few of continental origin (polluted) in winter and autumn.

The last group representing REMO's severe underestimations (Fig. 14) is characterized by air masses mainly of continental origin (Central and Eastern Europe), characterized by 

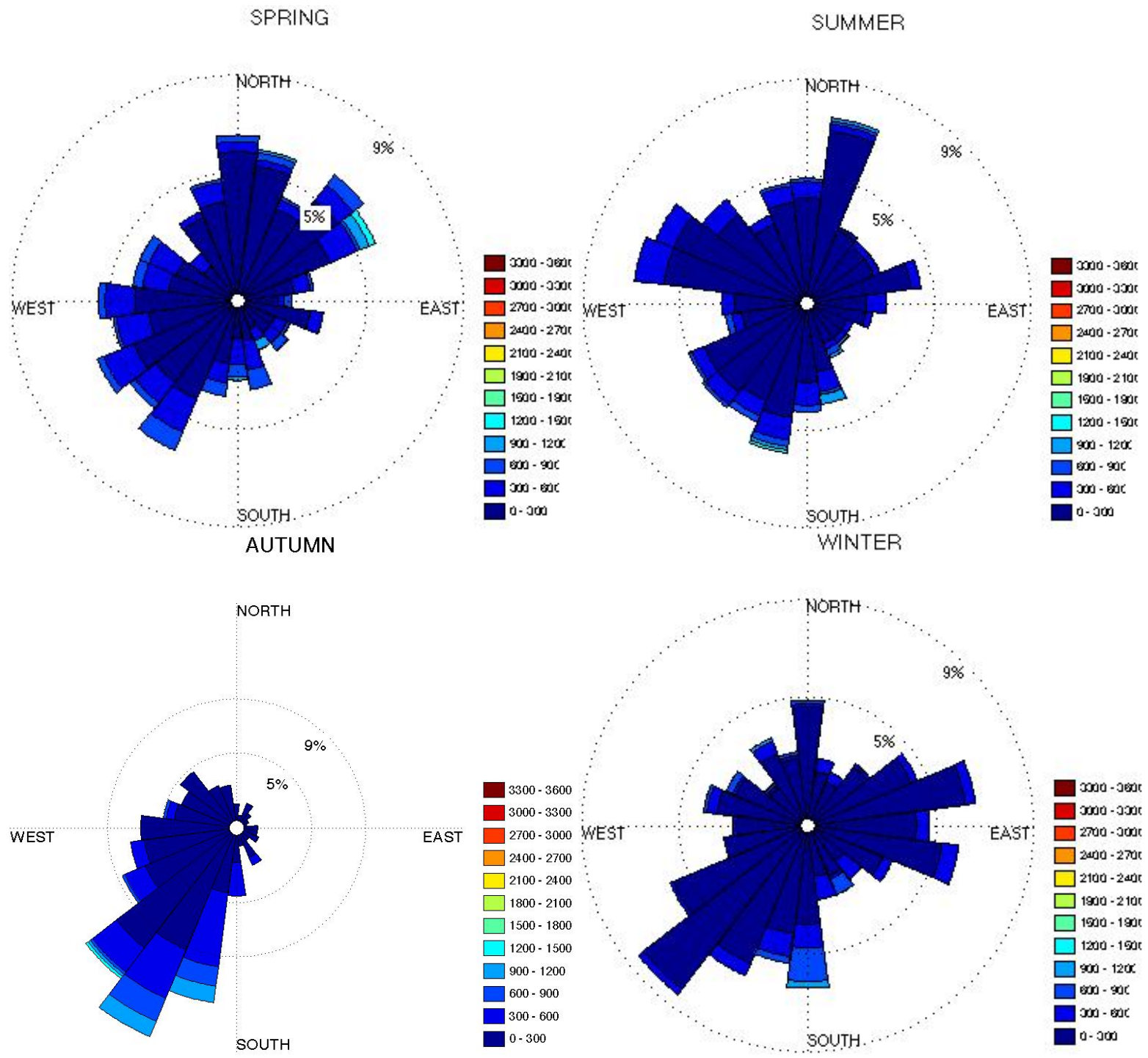

Fig. 11. The modelled seasonal wind directions (slices) and BC concentrations represented as a colour scheme (Hyytiälä 2005).

an elevated concentration of anthropogenic pollutions, most of them occurring during the winter and autumn. Our findings are in concordance with the results reported by Aurela et al. (2011) and Hyvärinen et al. (2011).

It has to be noted that - for the last case - the majority of the air masses arriving at Hyytiälä cross over southern Finland, collecting the $\mathrm{BC}$ emitted by the regional and local sources, and therefore the long-range and local/regional sources cannot be easily separated. However, this separation can be achieved within the model, by switching off the sources of black carbon in Finland and allowing only the contribution of the cross-border-transported BC. Fig. 15 presents the percentage of the cross-border $\mathrm{BC}$ to the total black carbon load. While both long-range transport and local and regional sources do contribute to atmospheric black carbon over Finland, highly populated areas are more influ- enced by local sources (central and southern Finland, especially Helsinki metropolitan area) while the remote areas are dominated by the long-range-transported $\mathrm{BC}$. In the region of Hyytiälä, the contribution of the cross-border BC is less than $30 \%$, making the local/regional emissions the main source of black carbon. Monthly median contribution of the longrange-transported $\mathrm{BC}$ in Hyytiälä in comparison to the normal BC median concentrations are presented in Fig. 16.

Within the local and regional emissions, traffic and domestic combustion (mainly wood burning) are the the key sources of black carbon (Kupiainen, 2006). When air masses are influenced by biomass burning, the presence of levoglucosan - a molecular marker of biomass burning aerosols produced by pyrolysis of cellulose and hemicellulose - can be detected and used as a qualitative indicator for $\mathrm{BC}$ originating from the biomass combustion (Kuo et al., 2008). 

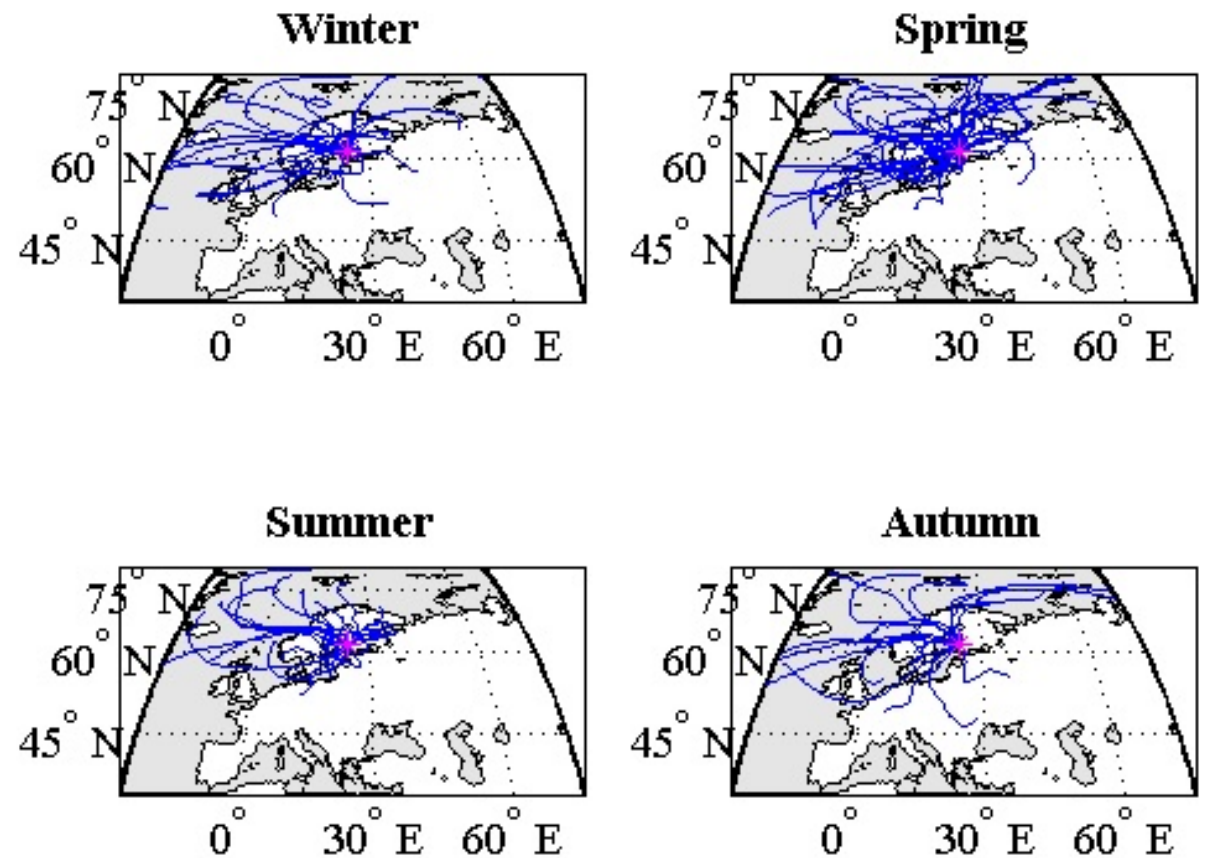

Fig. 12. Seasonal 4-day air mass back trajectories arriving at Hyytiälä (2005) for the samples where REMO-HAM is moderately (not more than $300 \mathrm{ng} \mathrm{m}^{-3}$ ) underestimating the measurements.
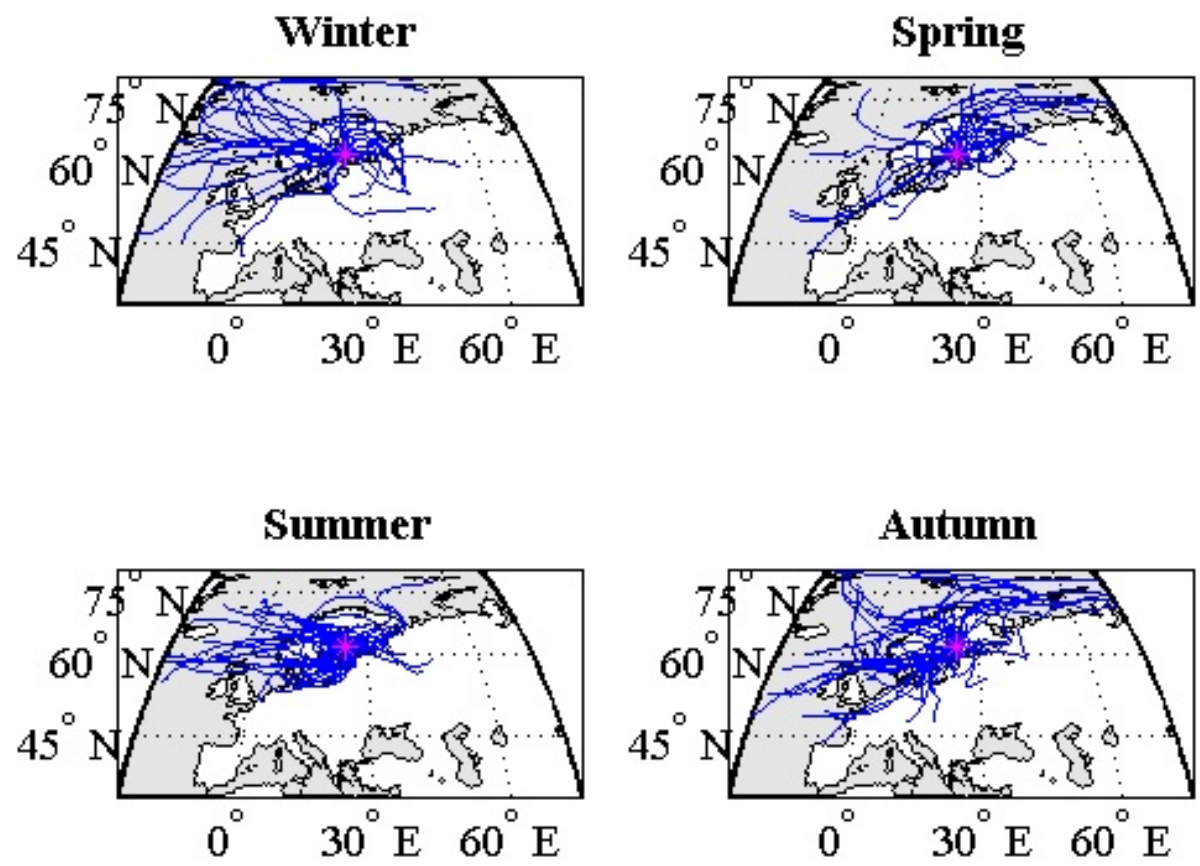

Fig. 13. Seasonal 4-day air mass back trajectories arriving at Hyytiälä (2005) for the samples where REMO-HAM is severely (more than $300 \mathrm{ng} \mathrm{m}^{-3}$ ) underestimating the measurements.

A series of research articles have reported various concentrations of levoglucosan in Hyytiälä. For instance, Saarnio et al. (2010) obtained an average levoglucosan concentration of $17 \mathrm{ng} \mathrm{m}^{-3}$ during spring 2007, while Yttri et al. (2011) obtained an average concentration of $4.6 \mathrm{ng} \mathrm{m}^{-3}$ for the late summer of 2009. The levoglucosan concentrations detected by Kourtchev et al. (2005) were relatively low during summer $2004\left(10 \mathrm{ng} \mathrm{m}^{-3}\right)$ and became the dominant organic species in the autumn samples $\left(29 \mathrm{ng} \mathrm{m}^{-3}\right)$. The authors concluded that this is an indicator for wood burning 

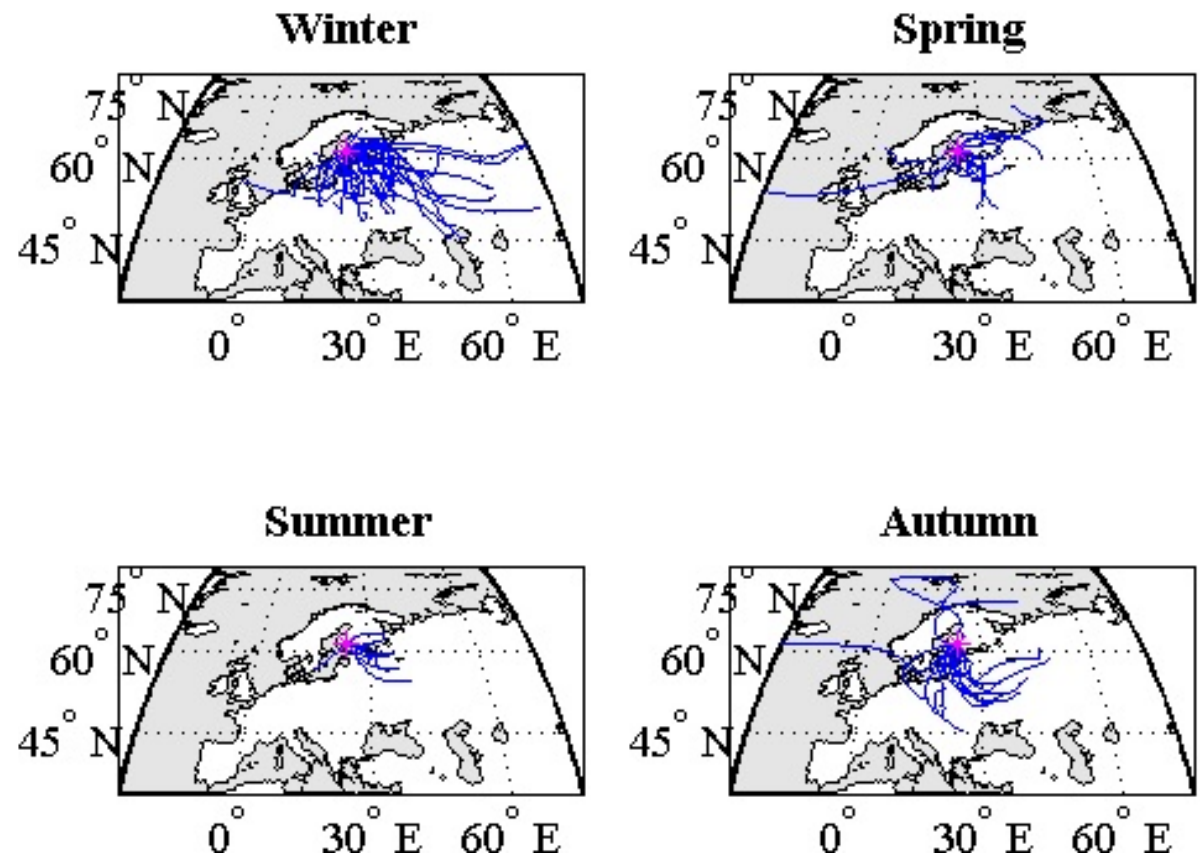

Fig. 14. Seasonal 4-day air mass back trajectories arriving at Hyytiälä (2005) for the samples where REMO-HAM is overestimating the measurements.

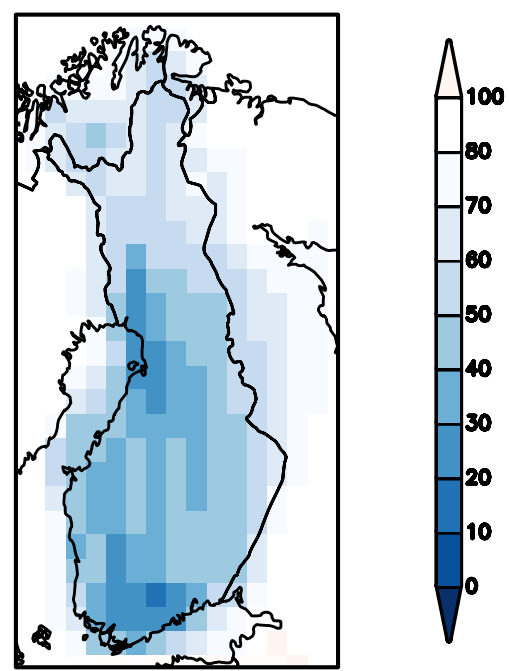

Fig. 15. The percentage of the cross-border BC to the total black carbon load obtained by switching off the emissions in Finland for the year 2005 .

taking place at or closed to the station in Hyytiälä, most likely for domestic heating purposes. A similar conclusion was drawn by Saarnio et al. (2010), who stated that the atmospheric levoglucosan in Hyytiälä is caused primarily by regional scale wood combustion, although in some cases the black carbon was originating from smokes transported from wild/agricultural fires (Saarikoski et al., 2007).

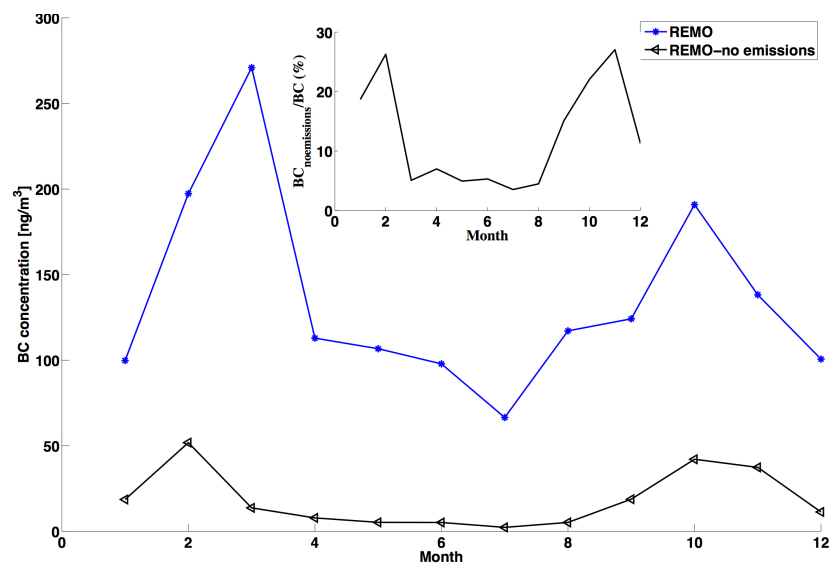

Fig. 16. Comparison of the monthly modelled median BC concentrations: blue stars: the full emissions run; black triangles: the model results when the BC emissions in Finland are switched off. The inside plot represents the percentage of the $\mathrm{BC}$ concentrations from the no-emissions run from the full-emissions run.

In conclusion, the presence of levoglucosan together with the drastic reduction of $\mathrm{BC}$ concentrations when the Finnish emissions are switched off hint to the fact that local and regional emissions have a significant contribution. Although there is an obvious contribution of the long-range-transported $\mathrm{BC}$, the model tendency to flatten the observed $\mathrm{BC}$ concentrations is most likely dominated by the inaccurate characterization of $\mathrm{BC}$ within the emission inventories, in particular the missing local-wood-burning emissions. However it is not 

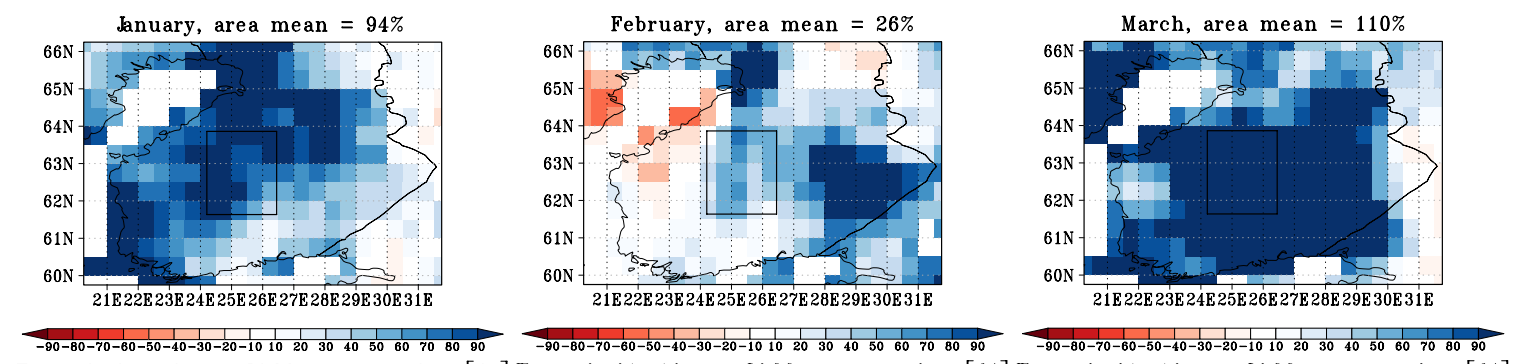

Precipitation difference in [\%] Precipitation difference in [\%] Precipitation difference in [\%]
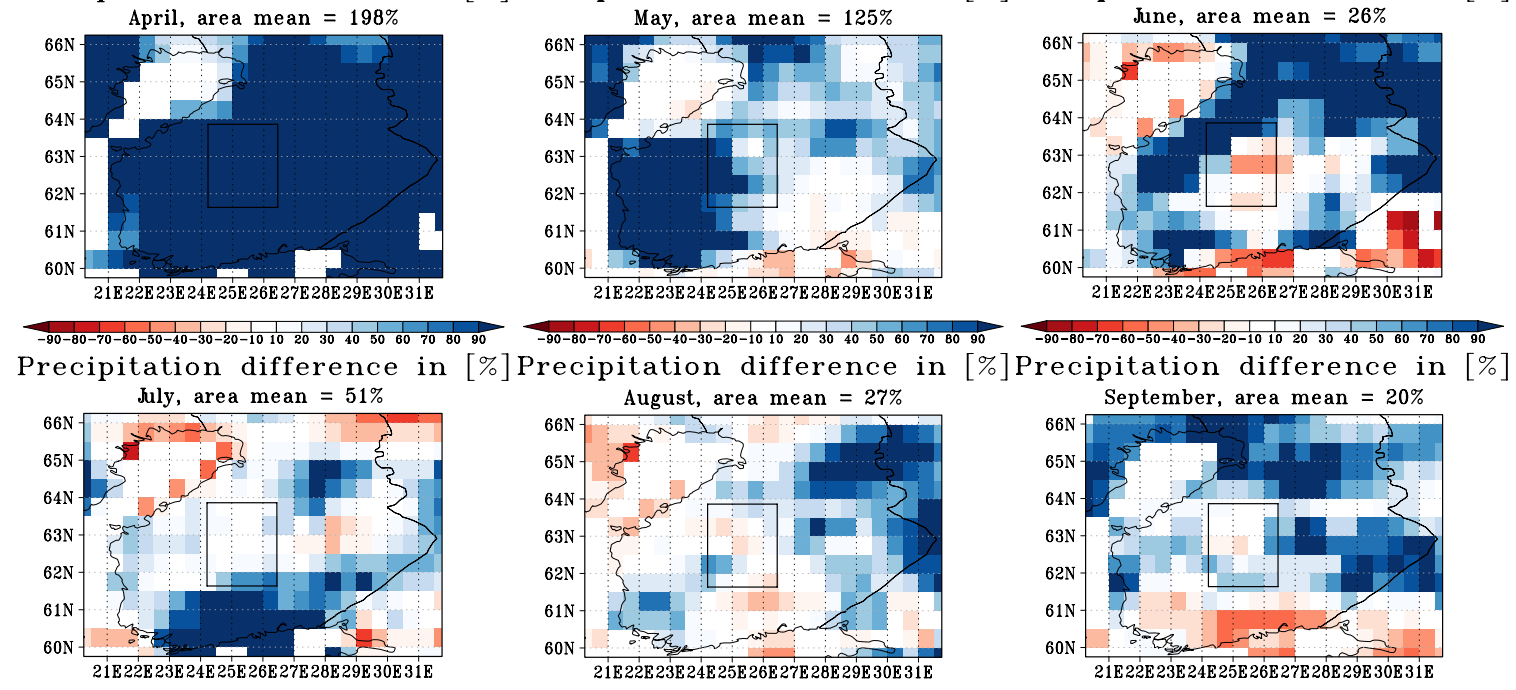

Precipitation difference in [\%] Precipitation difference in
July, area mean $=51 \%$
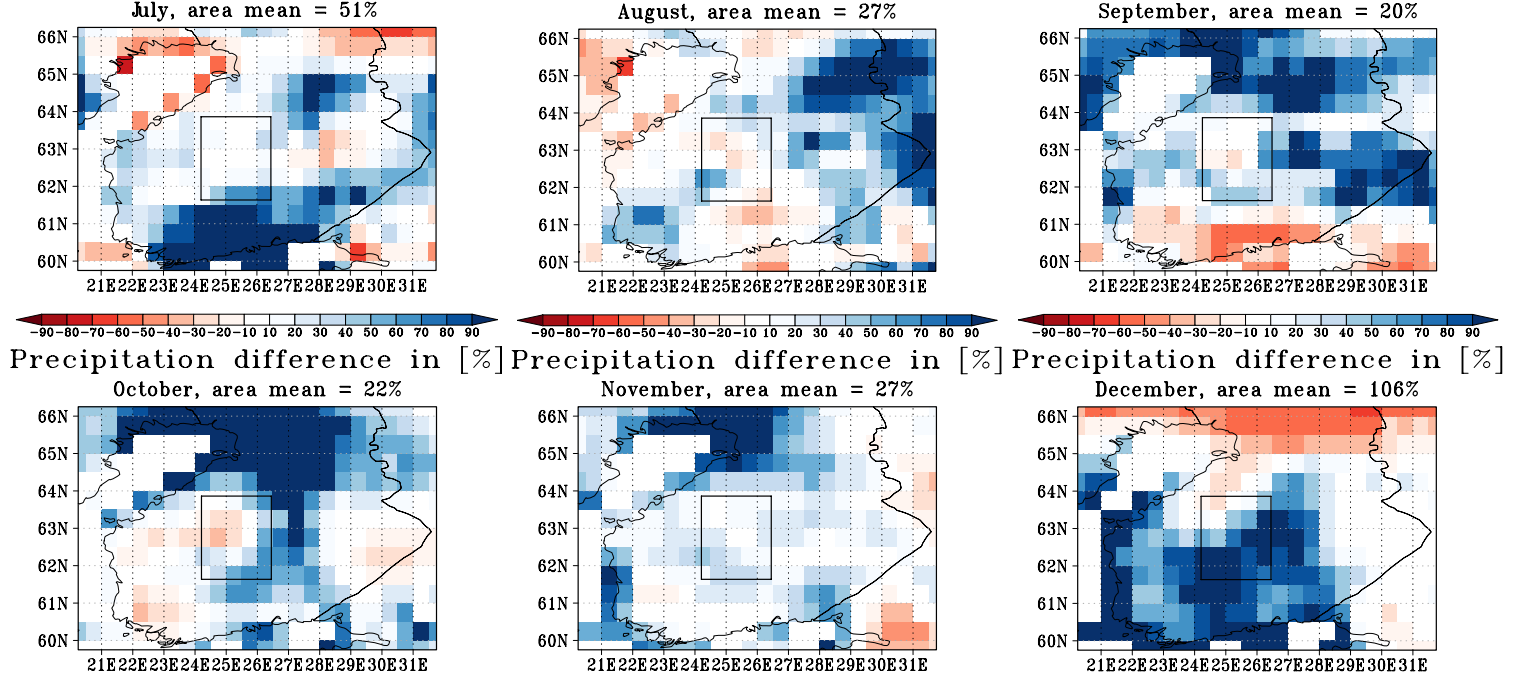

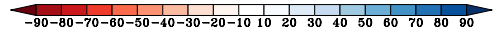

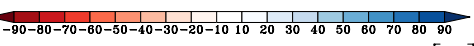

Precipitation difference in [\%] Precipitation difference in [\%]Precipitation difference in [\%]

Fig. 17. Monthly percentage difference for precipitation in southern Finland. Blue and red colours represent the model overestimation and underestimation, respectively. White represents agreement. The central grid in the outlined square indicates Hyytiälä location, while the number above each panel represents the mean precipitation difference for the square.

plausible to rule out other possible causes (inaccurate prediction of meteorology, various parameterizations etc.) .

\subsubsection{Precipitation and black carbon concentrations}

Wet removal is the dominant sink for the black carbon and thus a potential cause of the underestimated black carbon concentrations. We compared the model results against measurement data from CRU TS 3.0 (Jones et al., 2008). The CRU TS 3.0 dataset is available on a 0.5 degree grid, has a monthly time resolution, and covers all the land points of earth. The precipitation data from REMO-HAM were con- servatively remapped to the CRU grid so that a direct comparison is possible.

The monthly comparison of precipitation in southern Finland is presented in Fig. 17 as a percentage difference between the model output and the measurements. The blue colour marks the model overestimation of precipitation, which seemed to occur during each month, preponderantly in January, March, April, May, June and December. The red colour depicts model underestimation, and the area mean on top of each plot represents the mean precipitation difference around Hyytiälä. There was no obvious correlation between REMO's excessive precipitation and REMO's black carbon 

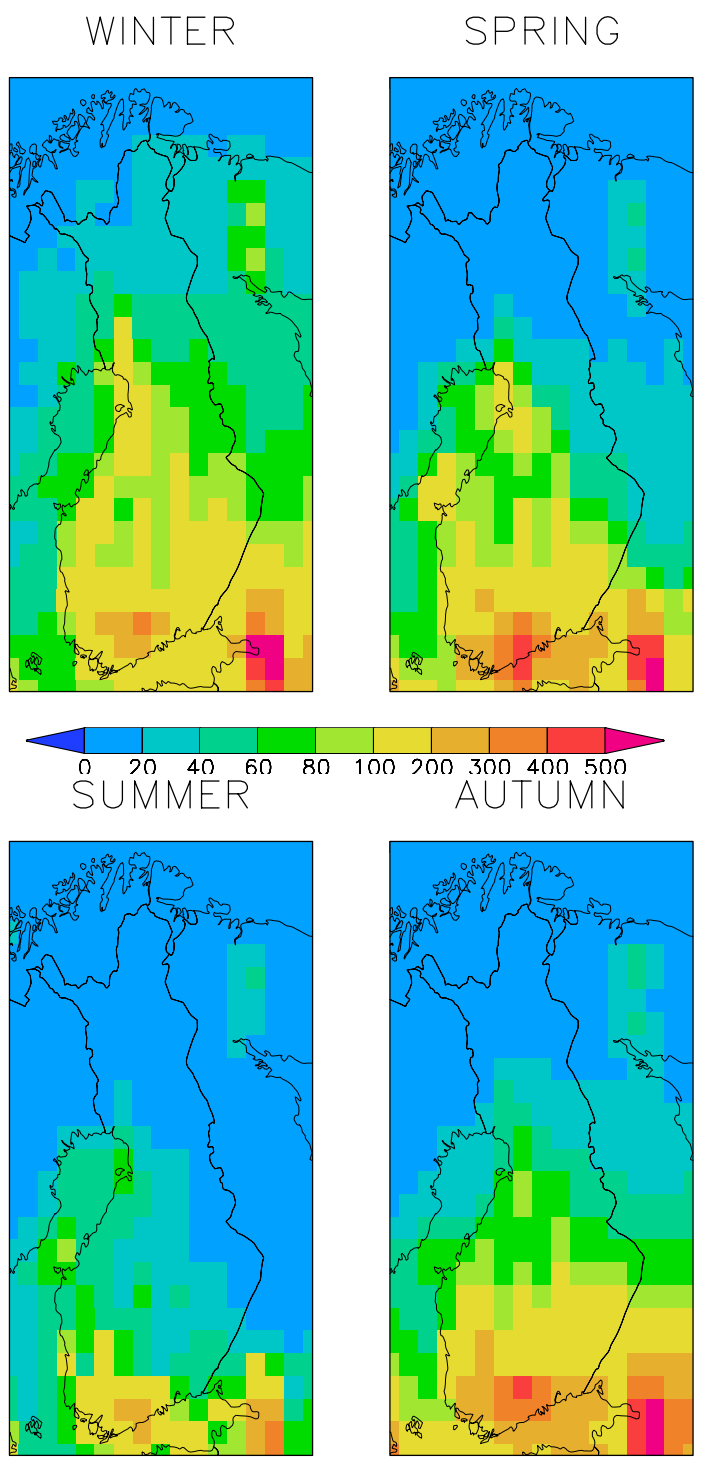

$0 \quad 20 \quad 40 \quad 60 \quad 80 \quad 100 \quad 200 \quad 300 \quad 400500$

Fig. 18. Modelled seasonal black carbon near-surface median concentration $\left[\mathrm{ng} \mathrm{m}^{-3}\right.$ ] over Finland for 2005.

underestimation. If the wet removal was the leading reason for the black carbon underestimation, we would expect a high percentage difference in precipitation during February (area mean of just $26 \%$ ), when the BC underestimation was highest, or a good agreement in precipitation in March (area mean of $110 \%$ ), when also the $\mathrm{BC}$ concentrations matched. The same reasoning can be applied for the remaining months: for April to August the REMO BC underestimation was similar, while the precipitation difference given by the area mean ranged from $26 \%$ in June to $198 \%$ in April. The only agreement between precipitation difference and BC underestimation was found in September, when both of the above quantities were small. It is possible that the overestimated precipi-
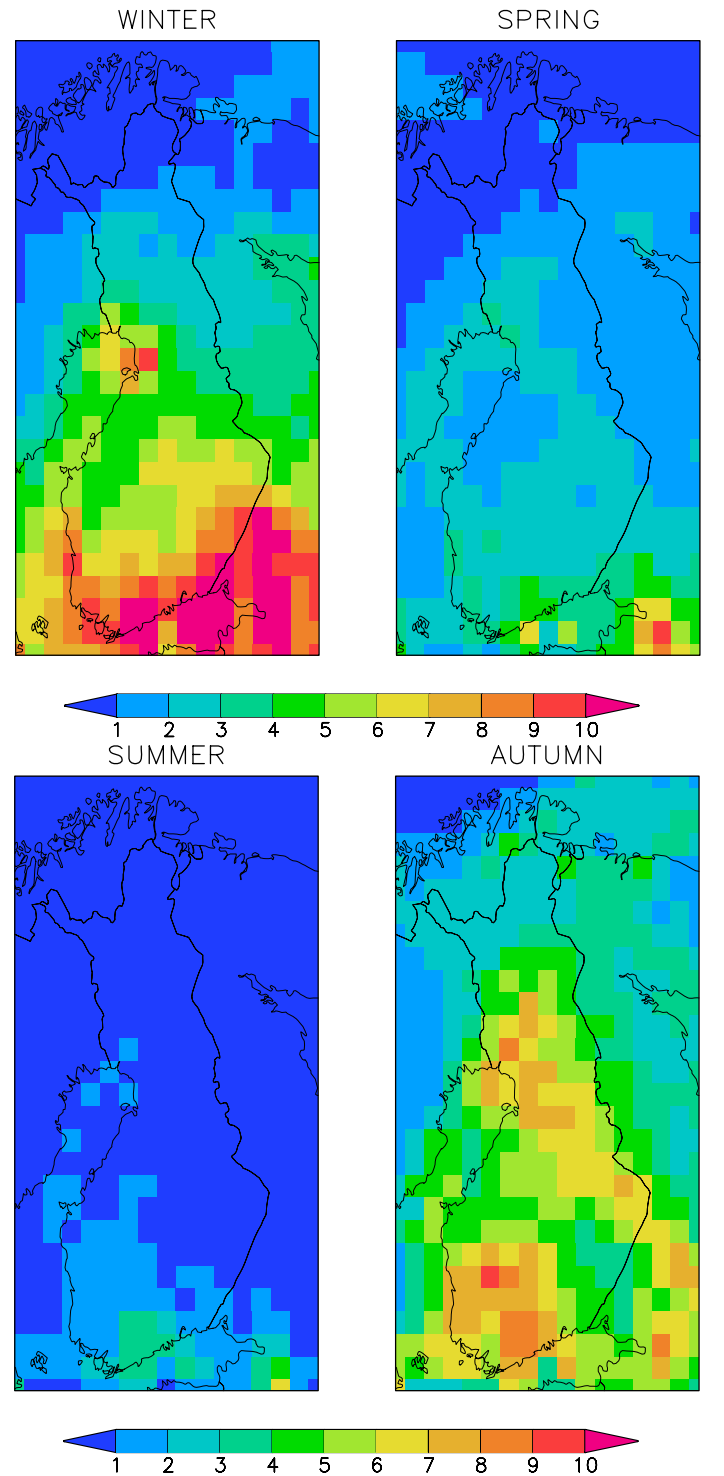

Fig. 19. Modelled seasonal black carbon deposition fluxes $\left[\mathrm{mg} / \mathrm{m}^{2}\right]$ over Finland for 2005.

tation might contribute to a certain extent to the underestimation of $\mathrm{BC}$ concentrations. However, the fact that no monthly correlation was observed suggests that the low BC fluxes in the emission inventories are the main reason for $\mathrm{BC}$ underestimation, rather than the model overestimating the wet removal.

\subsection{Modelled black carbon concentration and deposition over Finland}

The continuous REMO-HAM simulation for the year 2005 delivers a complete annual cycle of the black carbon concentration and deposition over the whole country. Fig. 18 presents the modelled near-surface BC median concentrations for all seasons. Each spatial figure exhibits a similar 


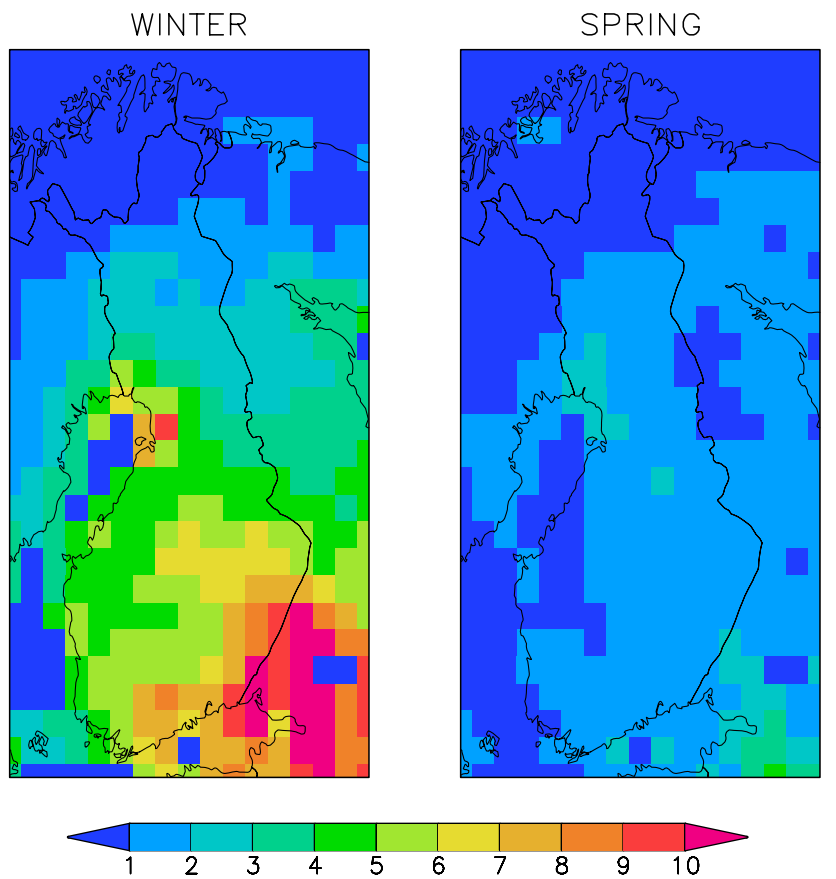

Fig. 20. Modelled black carbon deposition flux on snow $\left[\mathrm{mg} / \mathrm{m}^{2}\right]$ over Finland for winter and spring 2005.

pattern: a clean northern Finland atmosphere, with increasing black carbon concentrations southwards, reaching a maximum around the city of Helsinki. A similar pattern is found also for the cumulative concentrations over all vertical levels (not shown). The spatial distribution of black carbon concentration corresponds to high-emission regions with high population density (see Fig. 2 for comparison). The same figure reveals that the $\mathrm{BC}$ concentration is lower during the summer than during the other seasons over most of the domain. Given the results obtained by comparing the observed and modelled $\mathrm{BC}$ concentrations in various locations around Finland, we can assume that the real concentration values for the entire domain will exceed the model estimates by approximately a factor of two.

Figure 19 presents the total black carbon deposited during each season.The spatial distribution of the total deposition was correlated to the black carbon emissions (Fig. 2) and had a strong geographical and temporal variability: the largest deposition occurs in the higher populated regions, that is, in southern and central Finland, while northern Finland had the lowest deposition rate, due mainly to lower emissions. The black carbon deposition reached the highest rates during winter and autumn, declined significantly in spring and reached a minimum during the summer.

Wet and dry deposition rates have been considered separately. The dry deposition ranked in magnitude well below the wet deposition $(1.03 \mathrm{Gg}$ in comparison to $5.53 \mathrm{Gg}$ ), but it was more evenly distributed. Dry deposition reached its highest rates in southern Finland $(0.84 \mathrm{Gg}$ in comparison to
$0.12 \mathrm{Gg}$ in northern Finland). However, the wet deposition remained the dominant process of removing black carbon from the atmosphere during autumn, winter and spring, while in the summer the two removal mechanisms were similar in efficiency. Unfortunately, the lack of surface measurements of black carbon deposition did not allow us to properly evaluate the model performance in simulating this particular feature. Nevertheless, the model provides at least information on spatial and temporal distribution of $\mathrm{BC}$ concentrations and deposition, which can be used to investigate the black carbon deposition effects on snow over Finland.

In order to calculate the $\mathrm{BC}$ deposition on snow, information about the simulated snow depth (snow water equivalent) was used. The mass of black carbon deposited via dry and wet deposition were summed for all of the time steps in which the snow depth was over zero. Fig. 20 summarizes the seasonal black carbon deposition within the snowpack for winter and spring only, as during the summer the deposition on snow was practically zero and very small during the autumn. The total deposition amount of BC in Finland was $1071.52 \mathrm{mg} \mathrm{m}^{-2}$ in the winter months (January, February and December 2005) and $442.53 \mathrm{mg} \mathrm{m}^{-2}$ in spring, corresponding to $2.51 \mathrm{Gg}$ and $1.03 \mathrm{Gg}$, respectively. The total emission of black carbon in Finland is $2.0351 \mathrm{Gg}$ in winter, showing the contribution of the $\mathrm{BC}$ transported across the border. In spring, the BC emission reaches $2.0803 \mathrm{Gg}$, about 2 times higher than the deposited amount, leading to the idea that at least half of the emitted BC is exported. Several studies have investigated the $\mathrm{BC}$ deposition on snow at global level for various time periods. Skeie et al. (2011) using Oslo CTM2 chemical transport model calculated an average of $\mathrm{BC}$ deposited on snow during spring months of the year 2000 between $50-200 \mathrm{ng} \mathrm{g}^{-1}$ of snow for Finland. Flanner et al. (2007) applied the Snow, Ice, and Aerosol Radiative (SNICAR) model coupled to a general circulation model and obtained a similar BC deposition on snow range as Skeie et al. (2011), but for the year 1998. Our model result of about $131 \mathrm{ng} \mathrm{g}^{-1}$ for spring 2005 falls within the same order of magnitude. However, our result cannot be compared directly to the results reported in literature, as they are not from the same year.

\section{Summary and concluding remarks}

The aim of this study was to investigate the capability of the regional climate-aerosol model REMO-HAM to predict black carbon concentrations at various sites in Finland, with focus on Hyytiälä station. Several statistical tools were utilized in order to better evaluate the model's predictive ability. Each statistic was able to explain a certain aspect of the model and measurement comparison: the monthly median comparison illustrated the ability of the model to reproduce the seasonal pattern of the $\mathrm{BC}$ measurements, the overlap coefficient of two probability density functions offered 
an approach for the measurement of the agreement between two distributions in any distributional setting, and the $\mathrm{Z}$ score brought additional information on the agreement between shape and spread of the distributions of modelled and measured data. Together, these statistical tools generated a more complete picture on the behaviour of the regional aerosol climate model REMO-HAM. In addition to the statistical tools, wind directions and precipitation data were examined.

The main results of this study are the following:

1. The model is able to simulate to a certain extent the seasonal variation of $\mathrm{BC}$ concentrations, especially during the spring, summer and autumn seasons.

2. Satisfactory agreement between the model and measurements based on OVL and Z coefficients can be found for the same periods of time as listed above (OVL of $72 \%, 59 \%$ and $76 \%$ ).

3. The model is biased low with respect to the black carbon concentrations larger than $500 \mathrm{ng} \mathrm{m}^{-3}$ with about $60 \%$.

4. The model is biased high with respect to black carbon concentrations smaller than $250 \mathrm{ng} \mathrm{m}^{-3}$ with about $30 \%$.

5. The model compares well against the source areas of high black carbon concentrations.

6. The contribution of the modelled cross-bordertransported BC in Hyytiälä is less than $30 \%$ for the year 2005 .

7. The model overestimation of precipitation is most likely only partially responsible for the underestimation of black carbon concentrations.

8. REMO-HAM simulates a large spatial and seasonal variability of black carbon concentrations and deposition rates over Finland, reflecting the emission pattern.

9. The deposition of black carbon on snow has been estimated for winter and spring $2005(2.51 \mathrm{Gg}$ and $1.03 \mathrm{Gg}$, respectively) and compared to the emissions for the same seasons.

The above results indicate that the model's low bias for the black carbon concentrations is due mainly to the inaccuracy of the emission inventories, whose so-called black carbon data are apparently representative for elemental carbonlike substance (Vignati et al., 2010b). In addition, the local sources of black carbon - like wood burning emissions - are often not taken into account in the emission databases, also leading to serious underestimations.

The comparison results suggest a need for the development of a more comprehensive country-specific emission inventory as well as for a detailed study of the $\mathrm{BC}$ removal mechanisms. These questions will be addressed in the near future.

Acknowledgements. This work was supported by the Academy of Finland's Research Programme on Climate Change (FICCA) (project 140748), by the Finnish Ministry of the Environment, by Helsinki University Center for Environment HENVI, EU LIFE+ project LIFE09 ENV/FI/000572 MACEB and FCoE. Grateful acknowledgement for proofreading and correcting the English language goes to Declan O'Donnell.

Edited by: I. Riipinen

\section{References}

Allen, G., Lawrence, J., and Koutrakis, P.: Field validation of a semi-continuous method for aerosol black carbon (aethalometer) and temporal patterns of summertime hourly black carbon measurements in southwestern PA, Atmos. Environ., 33, 817-823, 1999.

Anttila, P., Makkonen, U., Hellén, H., Kyllönen, K., Leppänen, S., Saari, H., and Hakola, H.: Impact of the open biomass fires in spring and summer of 2006 on the chemical composition of background air in south-eastern Finland, Atmos. Environ., 42, 64726486, 2008.

Aurela, M., Saarikoski, S., Timonen, H., Aalto, P., Keronen, P., Saarnio, K., Teinilä, K., Kulmala, M., and Hillamo, R.: Carbonaceous aerosol at a forested and an urban background sites in Southern Finland, Atm. Environ., 45, 1394-1401, 2011.

Babich, P., Davey, M., Allen, G., and Koutrakis, P.: Method comparisons for particulate nitrate, elemental carbon, and $\mathrm{PM}_{2.5}$ mass in seven U.S. cities, J. Air \& Waste Manage. Assoc., 50, 1095 1105, 2000.

Bae, M.-S.and Hong, C.-S., Kim, Y., Han, J.-S., Moon, K.-J., Kondo, Y., Komazaki, Y., and Miyazaki, Y.: Intercomparison of two different thermal-optical elemental carbons and optical black carbon during ABC-EAREX2005, Atmos. Environ., 41, 27912803, doi:10.1016/j.atmosenv.2006.11.040, 2007.

Bond, T. C., Bhardwaj, E., Dong, R., Jogani, R., Jung, S., Roden, C., Streets, D., Fernandes, S., and Trautmann, N.: Historical emissions of black and organic carbon aerosol from energy-related combustion, 1850-2000, Global Biogeochem. Cy., 21, GB2018, doi:10.1029/2006GB002840, 2007.

Bond, T. C., Zarzycki, C., Flanner, M. G., and Koch, D. M.: Quantifying immediate radiative forcing by black carbon and organic matter with the Specific Forcing Pulse, Atmos. Chem. Phys., 11, 1505-1525, doi:10.5194/acp-11-1505-2011, 2011.

Bond, T. C., Streets, D., Yarber, K., Woo, J., and Klimont, Z.: A technology-based global inventory of black and organic carbon emissions from combustion, J. Geophys. Res. Atmos., 109, D14203, doi:10.1029/2003JD003697, 2004.

Cappa, C., Onasch, T., Massoli, P., Worsnop, D., Bates, T., Cross, E., Davidovits, P., Hakala, J., Hayden, K., Jobson, B., Kolesar, K., Lack, D., Lerner, B., Li, S.-M., Mellon, D., Nuaaman, I., Olfert, J., Petäjä, T., Quinn, P., Song, C., Subramanian, R., Williams, E., and Zaveri, R.: Radiative absorption enhancements due to the mixing state of atmospheric black carbon, Science, 337, 1078-1081, 2012 
Carmichael, G., Ferm, M., Thongboonchoo, N., Woo, J., Chan, L., Murano, K., P.H., V., Mossberg, C., R., B., Boonjawat, J., Upatum, P., Mohan, M., Adhikary, S., Shrestha, A., Pienaar, J., Brunke, E., Chen, T., Jie, T., Guoan, D., Peng, L., Dhiharto, S., Harjanto, H., Jose, A., Kimani, W., Kirouane, A., Lacaux, J.-P., Richard, S., Barturen, O., Cerda, J., Athayde, A., Tavares, T., Cotrino, J., and Bilici, E.: Measurements of sulfur dioxide, ozone and ammonia concentrations in Asia, Africa, and South America using passive samplers, Atmos. Environ., 37, 1293-1308, 2003.

Chevillard, A., Ciais, P., Karstens, U., Heimann, M., Schmidt, M., Levin, I. andjacob, D., Podzun, R., Kazan, V., Sartorius, H., and Weingartner, E.: Transport of ${ }^{222} \mathrm{Rn}$ using the regional climate model REMO: a detailed comparison with measurements over Europe, Tellus, 54B, 850-871, 2002a.

Chevillard, A., Karstens, U., Ciais, P., Lafont, S., and Heimann, M.: Simulation of atmospheric $\mathrm{CO}_{2}$ over Europe and western Siberia using the regional climate model REMO, Tellus, 54B, 872-894, 2002 b.

Chow, J. C., Watson, J. D.-P., Chen, L.-W., Sodeman, D., Lowenthal, D., Arnott, W., and Motallebi, N.: Aerosol light absorption, black carbon, and elemental carbon measurements at the Fresno Supersite, California, Atmos. Res., 93, 874-887, 2009.

Clemons, T. and Bradley Jr., E.: A nonparametric measure of the overlapping coefficient, Comp. Stat. Data Anal., 34, 51-61, 2000.

Cofala, J., Amann, M., Klimont, Z., Kupiainen, K., and HöglundIsaksson, L.: Scenarios of global anthropogenic emissions of air pollutants and methane until 2030, Atmos. Environ., 41, 84868499, doi:10.1016/j.atmosenv.2007.07.010, 2007.

Cooke, W. F., Liousse, C., Cachier, H., and Feichter, J.: Construction of a 11 fossil fuel emission data set for carbonaceous aerosol and implementation and radiative impact in the ECHAM4 mode, J. Geophy. Res., 104, 137-162, 1999.

Croft, B., Lohmann, U., and von Salzen, K.: Black carbon ageing in the Canadian Centre for Climate modelling and analysis atmospheric general circulation model, Atmos. Chem. Phys., 5, 19311949, doi:10.5194/acp-5-1931-2005, 2005.

Croft, B., Lohmann, U., Martin, R. V., Stier, P., Wurzler, S., Feichter, J., Posselt, R., and Ferrachat, S.: Aerosol size-dependent below-cloud scavenging by rain and snow in the ECHAM5HAM, Atmos. Chem. Phys., 9, 4653-4675, doi:10.5194/acp-94653-2009, 2009.

Davies, H.: A lateral boundary formulation for multi-level prediction models, Q. J. Roy. Meteor. Soc., 102, 405-418, 1976.

Decesari, S., Fuzzi, S., Facchini, M. C., Mircea, M., Emblico, L., Cavalli, F., Maenhaut, W., Chi, X., Schkolnik, G., Falkovich, A., Rudich, Y., Claeys, M., Pashynska, V., Vas, G., Kourtchev, I., Vermeylen, R., Hoffer, A., Andreae, M. O., Tagliavini, E., Moretti, F., and Artaxo, P.: Characterization of the organic composition of aerosols from Rondônia, Brazil, during the LBASMOCC 2002 experiment and its representation through model compounds, Atmos. Chem. Phys., 6, 375-402, doi:10.5194/acp6-375-2006, 2006.

Dentener, F., Kinne, S., Bond, T., Boucher, O., Cofala, J., Generoso, S., Ginoux, P., Gong, S., Hoelzemann, J. J., Ito, A., Marelli, L., Penner, J. E., Putaud, J.-P., Textor, C., Schulz, M., van der Werf, G. R., and Wilson, J.: Emissions of primary aerosol and precursor gases in the years 2000 and 1750 prescribed data-sets for AeroCom, Atmos. Chem. Phys., 6, 4321-4344, doi:10.5194/acp-6-
4321-2006, 2006.

Draxler, R. and Hess, G.: An overview of the HYSPLIT 4 modeling system for trajectories, dispersion and depostition, Austr. Meteorol. Mag., 47, 295-308, 1998.

Engler, C., Lihavainen, H., Komppula, M., Kerminen, V., Kulmala, M., and Viisanen, Y.: Continous measurements of aerosol properties at the Baltic Sea, Tellus B, 59, 728-741, 2007.

Flanner, M., Zender, C., Randerson, J., and Rasch, P.: Present-day climate forcing and response from black carbon in snow, J. Geophys. Res., D11202, doi:10.1029/2006JD008003, 2007.

Freedman, D. and Diaconis, P.: On the histogram as a density estimator:L 2 theory, Zeitschrift für Wahrscheinlichkeitstheorie und Verwandte Gebiete, 57, 453-476, doi:10.1007/BF01025868, 1981.

Furutani, H., Dallosto, M. and Roberts, G., and Prather, K.: Assessment of the relative importance of atmospheric aging on $\mathrm{CCN}$ activity derived from field observations, Atmos. Environ., 42, 3130-3142, 2008.

Gamnitzer, U., Karstens, U., Kromer, B., Neubert, R., Meijer, H., Schroeder, H., and Levin, I.: Carbon monoxide: A quantitative tracer for fossil fuel $\mathrm{CO}_{2}$ ?, J. Geophys. Res., 111, D22302, doi:10.1029/2005JD006966, 2006.

Gilardoni, S., Vignati, E., and Wilson, J.: Using measurements for evaluation of black carbon modeling, Atmos. Chem .Phys., 11, 439-455, doi:10.5194/acp-11-439-2011, 2011.

Granier, C., Bessagnet, B., Bond, T., D’Angiola, A., Van Der Gon, H. D., Frost, Heil, . A., Kaiser, J., Kinna, S., Klimont, Z., Kloster, S., Lamarque, J.-F., Liousse, C., Masui, T. andMeleux, F., Mieville, A., Ohara, T., Raut, J.-C., Riahi, K., Schultz, D., Smith, S., Thompson, A., van Aardenne, J. A., van der Werf, G., and van Vuuren, D.: Evolution of anthropogenic and biomass burning emissions of air pollutants at global and regional scales during the 1980-2010 period, Climatic Change, 109, 163-190, doi:10.1007/s10584-011-0154-1, 2011.

Hagler, G., Bergin, M., Smith, E., and Dibb, J. E.: A summer time series of particulate carbon in the air and snow at Summit, Greenland, J. Geophy. Res., 112, D21309, doi:10.1029/2007JD008993, 2007.

Hansen, J. and Nazarenko, L.: Soot climate forcing via snow and ice albedos, Proc. Natl. Acad. Sci. USA, 101, 423-428, 2004.

Hansen, J., Sato, M., Ruedy, R., Nazarenko, L., Lacis, A., Schmidt, G. A., Russell, G., Aleinov, I., Bauer, M., Bauer, S., Bell, N., Cairns, B., Canuto, V., Chandler, M., Cheng, Y., Del Genio, A., Faluvegi, G., Fleming, E., Friend, A., Hall, T., Jackman, C., Kelley, M., Kiang, N., Koch, D., Lean, J., Lerner, J., Lo, K., Menon, S., Miller, R., Minnis, P., Novakov, T., Oinas, V., Perlwitz, J., Perlwitz, J., Rind, D., Romanou, A., Shindell, D., Stone, P., Sun, S., Tausnev, N., Thresher, D., Wielicki, B., Wong, T., Yao, M., and Zhang, S.: Efficacy of climate forcings, J. Geophy. Res., 110, D18104, doi:10.1029/2005JD005776, 2005.

Hari, P. and Kulmala, M.: Station for Measuring EcosystemAtmosphere Relations (SMEAR II), Boreal Environ. Res., 10, 315-322, 2005.

Hart, A.: Mann-Whitney test is not just a test of medians: differences in spread can be important, Brit. Med. J., 323, 391-393, doi:10.1136/bmj.323.7309.391, 2001.

Hatakka, J., Aalto, T., Aaltonen, V., Aurela, M., Hakola, H., Komppula, M., Laurila, T., Lihavainen, H., Paatero, J., Salminen, K., and Viisanen, Y.: Overview of the atmospheric research activi- 
ties and results at Pallas GAW station, Boreal Environ. Res., 8, 365-384, 2003.

Haywood, J. M. and Shine, K. P.: The effect of anthropogenic sulfate and soot aerosol on the clear sky planetary radiation budget, Geophys. Res. Lett., 22, 603-606, 1995.

Hitzenberger, R., Petzold, A., Bauer, H., Ctyroky, P., Pouresmaeil, P., Laskus, L., and Puxbaum, H.: Intercomparison of thermal and optical measurement methods for elemental carbon and black carbon at an urban location, Environ. Sci. Technol., 40, 63776383, 2006.

Husain, L., Dutkiewicz, V., Khan, A., and Ghauri, B.: Characterization of carbonaceous aerosols in urban air, Atmos. Environ., 41, 6872-6883, 2007.

Hyvärinen, A.-P., Kolmonen, P., Kerminen, V.-M. V., Virkkula, A., Leskinen, A., Komppula, M., Hatakka, J., Burkhart, J., Stohl, A., Aalto, P., Kumala, M., Lehtinen, K., Viisanen, Y., and Lihavainen, H.: Aerosol black carbon at five background measurement sites over Finland, a gateway to the Arctic, Atmos. Environ., 45, 4042-4050, 2011.

Jacob, D.: A note to the simulation of the annual and inter-annual variability of the water budget over the Baltic Sea drainage basin, Meteorol. Amtos. Phys., 77, 61-73, 2001.

Jacob, D. and Podzun, R.: Sensitivity Studies with the Regional Climate Model REMO, Meteorol. Atmos. Phys., 63, 119-129, 1996.

Jacobson, M. Z.: Climate response of fossil fuel and biofuel soot, accounting for soot's feedback to snow and sea ice albedo and emissivity, J. Geophys. Res., 109, D21201, doi:10.1029/2004JD004945, 2004.

Jeong, C.-H., Hopke, P., Kim, E., and Lee, D.-W.: The comparison between thermal-optical transmittance elemental carbon and Aethalometer black carbon measured at multiple monitoring sites, Atmos. Environ., 38, 5193-5204, 2004.

Jones, P., Harris, I., and Univ. of East Anglia Climatic Research Unit (CRU): CRU Time Series (TS) high resolution gridded datasets, available online at: http://badc.nerc.ac.uk/view/badc. nerc.ac.uk__ATOM__dataent_1256223773328276, last access: 16 April 20132008.

Junninen, H., Lauri, A., Keronen, P., Aalto, P., Hiltunen, V., Hari, P., and Kulmala, M.: Smart-SMEAR: on-line data exploration and visualization tool for SMEAR stations, Boreal Environ. Res., 14, 447-457, 2009

Klimont, Z., Cofala, J., Xing, J., Wei, W., Zhang, C., Wang, S., Kejun, J., Bhandari, P., Mathura, R., Purohit, P., Rafaj, P., Chambers, A., Amann, M., and Hao, J.: Projections of $\mathrm{SO}_{2}, \mathrm{NO}_{\mathrm{x}}$, and carbonaceous aerosols emissions in Asia, Tellus B, 61, 602-617, doi:10.1111/j.1600-0889.2009.00428.x, 2009.

Koch, D., Schulz, M., Kinne, S., McNaughton, C., Spackman, J. R., Balkanski, Y., Bauer, S., Berntsen, T., Bond, T. C., Boucher, O., Chin, M., Clarke, A., De Luca, N., Dentener, F., Diehl, T., Dubovik, O., Easter, R., Fahey, D. W., Feichter, J., Fillmore, D., Freitag, S., Ghan, S., Ginoux, P., Gong, S., Horowitz, L., Iversen, T., Kirkev\&aring;g, A., Klimont, Z., Kondo, Y., Krol, M., Liu, X., Miller, R., Montanaro, V., Moteki, N., Myhre, G., Penner, J. E., Perlwitz, J., Pitari, G., Reddy, S., Sahu, L., Sakamoto, H., Schuster, G., Schwarz, J. P., Seland, Ø., Stier, P., Takegawa, N., Takemura, T., Textor, C., van Aardenne, J. A., and Zhao, Y.: Evaluation of black carbon estimations in global aerosol models, Atmos. Chem. Phys., 9, 9001-9026, doi:10.5194/acp-9-9001-2009, 2009.
Kourtchev, I., Ruuskanen, T., Maehaut, W., Kulmala, M., and Claeys, M.: Observation of 2-methyltetrols and related photooxidation products of isoprene in boreal forest aerosols form Hyytiälä. Finland, Atmos. Chem. Phys., 5, 2761-2770, doi:10.5194/acp-5-2761-2005, 2005.

Kulmala, M., Hämeri, K., Aalto, P. P., Mäkelä, J. M., Pirjola, L., Nilsson, E. D., Buzorius, G., Rannik, Ü., Dal Maso, M., Seidl, W., Hoffmann, T., Janson, R., Hansson, H.-C., Viisanen, Y., Laaksonen, A., and O'Dowd, C. D.: Overview of the international project on biogenic aerosol formation in the boreal forest (BIOFOR), Tellus B, 53, 324-343, 2001.

Kuo, L.-J., Herbert, B. A., and Louchouarn, P.: Can levoglucosan be used to characterize and quantify char/charcoal black carbon in environmental media?, Org. Geochem., 39, 1466-1478, 2008.

Kupiainen, K.: Emissions of primary carbonaceous particles, their uncertainties and spatial allocation in Finland, in: Proceedings of the IUAPPA Regional Conference, 2006.

Kupiainen, K. and Klimont, Z.: Primary emissions of fine carbonaceous particles in Europe, Atmos. Environ., 41, 2156-2170, doi:10.1016/j.atmosenv.2006.10.06, 2007.

Lamarque, J.-F., Bond, T., Eyring, V., Granier, C., Heil, A., Klimont, Z., Lee, D., Liousse, C., Mieville, A., Owen, B., Schultz, M., Shindell, D., Smith, S., Stehfest, E., Van Aardenne, J., Cooper, O., Kainuma, M., Mahowald, N., McConnell, J., Naik, V., Riahi, K., and van Vuuren, D.: Historical (1850-2000) gridded anthropogenic and biomass burning emissions of reactive gases and aerosols: methodology and application., Atmos. Chem. Phys., 10, 7017-7039, doi:10.5194/acp-10-7017-2010, 2010.

Langmann, B. and Heil, A.: Relese and dispersion of vegetation and peat fire emissions, Atmos. Chem. Phys., 4, 2145-2160, doi:10.5194/acp-4-2145-2004, 2004.

Langmann, B., Bauer, S. E., and Bey, I.: The influence of the global photochemical composition of the troposphere on European summer smog, part I: Application of a global mesoscale model chain, J. Geophys. Res., 108, 4146, doi:10.1029/2002JD002072, 2003.

Leskinen, A., Portin, H., Komppula, M., Miettinen, P., Arola, A., Lihavainen, H., Hatakka, J., Laaksonen, A., and Lehtinen, K. Overview of the research activities and results at Puijo semiurban measurement station, Boreal Environ. Res., 14, 576-590, 2009.

Levy, H., Schwarzkopf, D., Horowitz, L., Ramaswamy, V., and Findell, K.: Strong sensitivity of late 21 st century climate to projected changes in short-lived air pollutants, J. Geophys. Res.Atmos., 113, D06102, doi:10.1029/2007JD009176, 2008.

Lim, H.-J., Turpin, B., Edgerton, E., Hering, S., Allen, G., Maring, H., and Solomon, P.: Semicontinuous aerosol carbon measurements: comparison of Atlanta Supersite measurements, J. Geophys. Res., 108, 8419, doi:10.1029/2001JD001214, 2003.

Louis, J.-F.: A parametric model of vertical eddy fluxes in the atmosphere, Bound. Layer Meteorol., 17, 187-202, 1979.

Mellor, B. and Yamada, T.: A hierarchy of turbulence closure models for planetary boundary layers, J. Atmos. Sci, 31, 1791-1806, 1974.

Miyazaki, Y., Kondo, Y., Sahu, L., Imaru, J., Fukushima, N., and Kano, M.: Performance of a newly designed continuous soot monitoring system (COSMOS), J. Environ. Qual., 10, 11951201, doi:10.1039/b806957c, 2008. 
Nordeng, T.: Extended versions of the convective parametrization scheme at ECMWF and their impact on the mean and transient activity of the model in Tropics., Tech. rep., ECMWF, Shineld Park, Reading, RG2 9AX, UK, 1994.

Pietikäinen, J.-P., O’Donnell, D., Teichmann, C., Karstens, U., Pfeifer, S., Kazil, J., Podzum, R., Rast, S., Fiedler, S., Kokkola, H., Birmili, W., O’Dowd, C., Baltensperger, U., Weingartner, E., Gehrig, R., Spindler, G., Kulmala, M., Feichter, J., Jacob, D., and Laaksonen, A.: Implementation of the HAM-M7 aerosol module and ECHAM5 cloud physics in the regional model REMO, Geosci. Model Dev. Discuss., in preparation 2012.

Pöschl, U.: Atmospheric Aerosols: Composition, Transformation, Climate and Health Effects, Angewandte Chemie International Edition, 44, 7520-7540, doi:10.1002/anie.200501122, 2005.

Ramanathan, V. and Carmichael, G.: Global and regional climate changes due to black carbon, Nature Geosci., 1, 221-227, 2008.

Roeckner, E., Arpe, K., Bengtsson, L., Christoph, M., Claussen, M. andDumenil, L., Esch, M., Schlese, U., and Schulzweida, U.: The atmospheric general circulation model ECHAM4: Model description and simulation of present-day climate., Tech. Rep. 218, Max Planck Institute for Meteorology, 1996.

Roeckner, E., Baeuml, G., Bonventura, L., Brokopf, R., Esch, M., Giorgetta, M., Hagemann, S., Kirchner, I., Kornblueh, L., Manzini, E., Rhodin, A., Schlese, U., Schulzweida, U., and Tompkins, A.: The atmospheric general circulation model ECHAM5. PART I: Model description., Tech. Rep. 349, Max Planck Institute for Meteorology, 2003.

Saarikoski, S., Sillanpää, M., Sofiev, M., T. H., Saarnio, K., Teinilä, K., Karppinen, A., Kukkonen, J., and Hillamo, R.: Chemical composition of aerosol during major biomass burning episode over northern Europe in spring 2006: experimental and modelling assesments, Atmos. Environ., 41, 3577-3589, 2007.

Saarnio, K., Teinilä, K., Aurela, M., Timonen, H., and Hillamo, R.: High-performance anion exchange chromatography-mass spectrometry method for determination of levoglucosan, mannosan and galactosan in atmospheric fine particulate matter, Anal. Bioanal. Chem., 398, 2253-2264, 2010.

Sahu, L., Kondo, Y., Miyazaki, Y., Kuwata, M., Koike, M., Takegawa, N., Tanimoto, H., Matsueda, H., Yoon, S., and Kim, Y.: Anthropogenic aerosols observed in Asian continental outflow at Jeju Island, Korea, in spring 2005, J. Geophys. Res., 114, D03301, doi:10.1029/2008JD010306, 2009.

Schaap, M., Van Der Gon, H. A. C. D., Dentener, F. J., Visschedijk, A. J. H., Van Loon, M., ten Brink, H. M., Putaud, J. P., Guillaume, B., Liousse, C., and Builtjes, P. J. H.: Anthropogenic black carbon and fine aerosol distribution over Europe, J. Geophys. Res., 109, D18207, doi:10.1029/2003JD004330, 2004.

Schwarz, J., Spackman, J., Gao, R., Watts, L., Stier, P., Schulz, M., Davis, S., C., W. S., and Fahley, D.: Global scale black carbon profiles observed in the remote atmosphere and compared to models, Geophys. Res. Lett., 37, L118812, doi:10.1029/2010GL044372, 2010.

Simpson, D., Yttri, K., Klimont, Z., Kupiainen, K., Caseiro, A., Gelencser, A., Pio, C., Puxbaum, H., and Legrand, M.: Modeling carbonaceous aerosol over Europe: Analysis of the CARBOSOL and EMEP EC/OC campains, J. Geophys. Res., 112, doi:10.1029/2006JD008158, 2007.

Skeie, R., Berntsen, T., Myhre, G., Pedersen, C., Ström, J., Gerland, S., and Ogren, J. A.: Black carbon in the atmosphere and snow, from pre-industrial times until present, Atmos. Chem. Phys., 11, 6809-6836, doi:10.5194/acp-11-6809-2011, 2011.

Smolarkiewicz, P. K.: Simple positive definite advection scheme with small implicit diffusion., Mon. Weather Rev., 111, 479-486, 1983.

Smolarkiewicz, P. K.: A fully multidimensional positive definite advection transport algorithm with small implicit diffusion., J. Comput. Phys., 54, 325-362, 1984.

Sogacheva, L., Dal Maso, M., Kerminen, V., and Kulmala, M.: Probablility of nucleation events and aerosol particle concentration in different ai mass types arriving at Hyytiälä, southern Finland, based on back trajectories analysis, Boreal Environ. Res., 10, 479-491, 2005.

Solmon, F., Giorgi, F., and Liousse, C.: Aerosol modelling for regional climate studies: application to anthropogenic particles and evaluation over a European/African domain, Tellus, 58B, 51-72, 2006.

Stier, P., Feichter, J., Kinne, S., Kloster, S., Vignati, E., Wilson, J., Ganzeveld, L., Tegen, I., Werner, M., Balkanski, Y., Schulz, M., Boucher, O., Minikin, A., and Petzold, A.: The aerosolclimate model ECHAM5-HAM, Atmos. Chem. Phys., 5, 1125 1156, doi:10.5194/acp-5-1125-2005, 2005.

Tegen, I., Hollrig, P., Chin, M., Fung, I., Jacob, D., and Penner, J.: Contribution of different aerosol species to the global aerosol extinction optical thickness, J. Geophy. Res., 102, 23895-23915, 1997.

Textor, C., Schulz, M., Guibert, S., Kinne, S., Balkanski, Y., Bauer, S., Berntsen, T., Berglen, T., Boucher, O., Chin, M., Dentener, F., Diehl, T., Easter, R., Feichter, H., Fillmore, D., Ghan, S., Ginoux, P., Gong, S., Grini, A., Hendricks, J., Horowitz, L., Huang, P., Isaksen, I., Iversen, I., Kloster, S., Koch, D., Kirkevåg, A., Kristjansson, J. E., Krol, M., Lauer, A., Lamarque, J. F., Liu, X., Montanaro, V., Myhre, G., Penner, J., Pitari, G., Reddy, S., Seland, $\emptyset$., Stier, P., Takemura, T., and Tie, X.: Analysis and quantification of the diversities of aerosol life cycles within AeroCom, Atmos. Chem. Phys., 6, 1777-1813, doi:10.5194/acp-6-1777-2006, 2006.

Tiedtke, M.: A comprehensive mass flux scheme for cumulus parameterization in large-scale models., Mon. Weather Rev., 117, 1779-1800, 1989.

Tsyro, S., Simpson, D., Tarrason, L., Klimont, Z., Kupiainen, K., Pio, C., and Yttri, K.: Modeling of elemental carbon over Europe, J. Geophys. Res., 112, D23S19, doi:10.1029/2006JD008164, 2007.

UNEP and WMO: Integrated Assessment of Black Carbon and Tropospheric Ozone: Summary for Decision Makers, www.wmo.int/ pages/prog/arep/gaw/documents/BlackCarbon_SDM.pdf, 2011.

Uno, I., Carmichael, G. R., Streets, D., Satake, S., Takemura, T., Woo, J., Uematsu, M., and Ohta, S.: Analysis of surface black carbon distributions during ACE-Asia using a regional-scale aerosol model, J. Geophy. Res., 108, 8636, doi:10.1029/2002JD003252, 2003.

Vignati, E., Wilson, J., and Stier, P.: M7: An efficient size-resolved aerosol microphysics module for large-scale aerosol transport models., J. Geophys. Res., 109, D22202, doi:10.1029/2003JD004485, 2004.

Vignati, E., Facchini, M. C., Rinaldi, M., Scanell, C., Ceburnis, D., Sciare, J., Kanakidou, M., Myriokefalitakis, S., and O`Dowd, C. D.: Global scale emission and distribution of sea spray 
aerosol: sea-salt and organic enrichment, Atmos. Environ., 44, 670-677, doi:10.1016/j.atmosenv.2009.11.013, 2010a.

Vignati, E., Karl, M., Krol, M., Wilson, J., Stier, P., and Cavalli, F.: Sources of uncertainties in modelling black carbon at the global scale, Atmos. Chem. Phys., 10, 2595-2611, doi:10.5194/acp-102595-2010, 2010b.

Williams, J., Crowley, J., Fischer, H., Harder, H., Martinez, M., Petäjä, T., Rinne, J., Bäck, J., Boy, M., Dal Maso, M., Hakala, J., Kajos, M., Keronen, P., Rantala, P., Aalto, J., Aaltonen, H., Paatero, J., Vesala, T., Hakola, H., Levula, J., Pohja, T., Herrmann, F., Auld, J., Mesarchaki, E., Song, W., Yassaa, N., Nölscher, A., Johnson, A. M., Custer, T., Sinha, V., Thieser, J., Pouvesle, N., Taraborrelli, D., Tang, M. J., Bozem, H., Hosaynali-Beygi, Z., Axinte, R., Oswald, R., Novelli, A., Kubistin, D., Hens, K., Javed, U., Trawny, K., Breitenberger, C., Hidalgo, P. J., Ebben, C. J., Geiger, F. M., Corrigan, A. L., Russell, L. M., Ouwersloot, H. G., Vilà-Guerau de Arellano, J., Ganzeveld, L., Vogel, A., Beck, M., Bayerle, A., Kampf, C. J., Bertelmann, M., Köllner, F., Hoffmann, T., Valverde, J., González, D., Riekkola, M.-L., Kulmala, M., and Lelieveld, J.: The summertime Boreal forest field measurement intensive (HUMPPA-COPEC-2010): an overview of meteorological and chemical influences, Atmos. Chem. Phys., 11, 10599-10618, doi:10.5194/acp-11-10599-2011, 2011.
Wu, J., Jiang, W., Fu, C., Su, B., Liu, H., and Tang, J.: Simulation of the radiative effect of black carbon aerosols and the regional climate response over China, Adv. Atmos. Sci., 21, 637-649, 2004.

Wu, J., Fu, C., Xu, Y., Tang, J., Wang, W., and Wang, Z.: Simulation of direct effects of black carbon aerosol and temperature and hydrological cycle in Alia by a Regional Climate Model, Meteorol. Atmos. Phys., 100, 179-193, doi:10.1007/s00703-008-0302y, 2008.

Yttri, K. E., Simpson, D., Nøjgaard, J. K., Kristensen, K., Genberg, J., Stenström, K., Swietlicki, E., Hillamo, R., Aurela, M., Bauer, H., Offenberg, J. H., Jaoui, M., Dye, C., Eckhardt, S., Burkhart, J. F., Stohl, A., and Glasius, M.: Source apportionment of the summer time carbonaceous aerosol at Nordic rural background sites, Atmos. Chem. Phys., 11, 13339-13357, doi:10.5194/acp11-13339-2011, 2011. 